\title{
YOU CAN'T TAKE IT WITH YOU? \\ IMMIGRANT ASSIMILATION AND \\ THE PORTABILITY OF HUMAN CAPITAL
}

Rachel M. Friedberg

Working Paper 5837

NATIONAL BUREAU OF ECONOMIC RESEARCH

1050 Massachusetts Avenue

Cambridge, MA 02138

November 1996

I would like to thank Joshua Angrist, David Cutler, Henry Farber, Stanley Fischer, Lawrence Katz, and David Weil for many helpful discussions; Alexander Cavallo for able research assistance; and Michal Peleg of the Social Sciences Data Archive at the Hebrew University of Jerusalem for providing access to the data. Financial support from the Maurice Falk Institute for Economic Research in Israel, the Program for the Study of the Israeli Economy at MIT, and the U.S. Department of Education is gratefully acknowledged. All errors are the author's alone. This paper is part of NBER's research program in Labor Studies. Any opinions expressed are those of the author and not those of the National Bureau of Economic Research.

(C) 1996 by Rachel M. Friedberg. All rights reserved. Short sections of text, not to exceed two paragraphs, may be quoted without explicit permission provided that full credit, including $\odot$ notice, is given to the source. 
You Can't Take It With You? Immigrant

Assimilation and the Portability of Human Capital

Rachel M. Friedberg

NBER Working Paper No. 5837

November 1996

JEL Nos. J61, J24

Labor Studies

\begin{abstract}
The national origin of an individual's human capital is a crucial determinant of its value. Education acquired abroad is significantly less valued than education obtained domestically. This difference can fully explain the earnings disadvantage of immigrants relative to comparable natives in Israel. Variation in the return to foreign schooling across origin countries may reflect differences in its quality and compatibility with the host labor market. Three factors - language proficiency, domestic labor market experience, and further education following immigration - appear to raise the return to education acquired abroad, suggesting a compound benefit of policies encouraging immigrants to obtain language and other training.
\end{abstract}

Rachel M. Friedberg

Department of Economics

Box B

Brown University

Providence, RI 02912

and NBER

rachel_friedberg@brown.edu 


\section{Introduction}

In recent years, much attention has been devoted in the labor literature to the question of immigrant labor market assimilation. Upon arrival in their host country, immigrants usually command lower wages than native-born workers with comparable measured characteristics. The literature has focussed on quantifying the size of this initial earnings differential and the rate at which it diminishes with time since migration (see Chiswick 1978a, Borjas 1985, Friedberg 1992, LaLonde and Topel 1992, Baker and Benjamin 1994). At issue is whether immigrants ever attain earnings parity with natives and if so, how long this process takes. A related question is how the earnings gap differs for immigrants from different countries and different arrival cohorts (Borjas 1992, Chiswick 1986, and Funkhouser and Trejo 1992).

The innovation of this paper is to introduce to this analysis a distinction between human capital which was acquired abroad and human capital acquired domestically. Foreign and domestic human capital may not be very close substitutes, and considering them as a homogeneous factor may be misleading. Many immigrants complete their schooling in their countries of origin. Many, however, immigrate at young ages and obtain virtually all their human capital after immigration. A sizable number possess a combination of foreign and domestic human capital. Thus, although previous work on immigrant and native earnings has allowed the return to human capital to differ for immigrants and natives, doing so is not equivalent to distinguishing between domestic- and foreign-source human capital in the analysis of earnings determination. ${ }^{1}$

This study demonstrates that the most important factor determining the gap in the standard human-capital-corrected earnings of immigrants and natives is the source of their human capital.

${ }^{1}$ Chiswick (1978a) considers the difference in the return to foreign and U.S. schooling, but does not bring this directly to the question of immigrant assimilation. 
Foreign human capital often - although not always - earns a lower return than domestic human capital, and this fact alone is sufficient to fully explain the residual earnings disadvantage of immigrants.

The data most commonly used to study immigrants in the United States is the series of of public-use microdata samples of the U.S. Census of Population. These data do not contain adequate information to reliably determine the source of an immigrant's education. There is no direct measure of where schooling was obtained, and the information on an immigrant's year of arrival, which could be used to impute it, is reported in bracketed form. It is therefore not feasible to analyze the importance of human capital source in this data ${ }^{2}$.

The Census of Population in Israel lends itself more readily to this kind of study. The Israeli case also provides a large, rich and varied pool of immigrants to observe. They have come from a wide range of countries and with vastly different educational and occupational backgrounds. The lesser degree of economic self-selection among immigrants to Israel ${ }^{3}$ also makes it well suited to this study.

This paper first establishes that the national origin of an individual's human capital is a crucial determinant of its return. It shows that the gap in the residual earnings of immigrant and native workers becomes insignificant once this factor is taken into account. It then goes on to show when the difference in returns is most marked and what factors mitigate it. Section II of the paper expands on the questions to be addressed in the analysis. The third section provides basic facts about immigration to Israel and describes the data used. Section IV examines the effects of immigrant

2 The 1976 Survey of Income and Education is a U.S. dataset containing direct information on country of schooling, but the sample of immigrants is small. See Borjas (1982) and Friedberg (1993) for papers using the SIE.

${ }^{3}$ see Bahral (1965) and Chiswick (1979). 
status, continent of origin, and length of residence on earnings. The fifth section compares returns to schooling obtained in the country of origin and in Israel. It analyzes the effect of foreign schooling on earnings, and whether certain factors-- including Hebrew language proficiency, domestic labor market experience, and domestic education- can raise the return to foreign schooling. This is followed by an analysis of the extent to which the portability of education depends on its level or configuration, in terms of type and source. The final section summarizes and discusses implications for the immigration literature and for immigration policy.

\section{Immigrants' Earnings and the Return to Schooling}

An important determinant of immigrants' economic success is the value in their destination country of the human capital they accumulated in their countries of origin, or the "portability" of their human capital. This paper investigates the returns to human capital acquired abroad and domestically, and how the returns received by immigrants compare to those of the native-born. Throughout, years of schooling are used as an index of human capital. ${ }^{4}$ The focus is on four parameters: (1) the return to foreign schooling for immigrants (both the initial level and changes in it with duration of residence in the host country); (2) the return to domestic schooling for immigrants; (3) the return to domestic schooling for natives; and (4) the interaction of foreign schooling with domestic human capital- schooling, labor market experience, and language skills.

The first parameter reflects the degree to which the education immigrants acquired in their countries of origin is transferable into earnings potential in the destination country. Differences across origin groups in the value placed on foreign education may stem from two factors. First, school quality varies considerably across countries. Immigrants from developed countries, for

\footnotetext{
${ }^{4}$ Becker (1975).
} 
example, might be expected to receive a higher return to their foreign education than immigrants from developing countries, because schooling is generally of lower quality in the latter. A second important factor is the compatibility of the education received abroad with the educational requirements of the host-country labor market. The more similar the origin and destination countries in terms of their levels of economic development, industrial and occupational structures, institutional settings, etc., the more likely it is that an education received in the origin country will be highly valued in the destination labor market. Even within country of origin, the level and type of education is likely to be important for its portability. For example, primary school might transfer well for many origin groups, while Law and other professional schooling might not.

When immigrants first arrive in a new country, they are at a disadvantage in the labor market, relative to natives with comparable demographic characteristics and skill levels. One reason is that natives have many country-specific skills and information that immigrants lack. As immigrants spend time in the host country and begin to acquire this country-specific knowledge, their labor market performance may be expected to improve, relative to their native counterparts. The rate at which the earnings gap between immigrants and natives narrows with years since migration is referred to here as the "assimilation rate".

The earnings of both highly educated and less educated immigrants are often compressed upon their arrival in the host country, with both groups working in low-skill jobs that require little language proficiency or other country-specific human capital. Over time, as they gain exposure to the new labor market, immigrants improve in their abilities to maximize the return to their origincountry skills through several types of learning. These include learning by doing on the job, accumulating more information about the host labor market, and engaging in search to find better earnings opportunities and job matches. As a result, immigrants may gradually sort themselves into 
more differentiated occupations, resulting in a rise in educational wage differentials among immigrants with duration of residence in the host country. ${ }^{5}$ A rise with time since migration in the return to schooling obtained abroad is definitionally equivalent to a higher assimilation rate for better educated immigrants.

In addition to education acquired abroad, education obtained subsequent to migration is an important component of immigrants' human capital. Nineteen percent of the immigrants in the sample used here received all their schooling domestically, and $27.5 \%$ attended school both before and after immigrating. The return to domestic schooling for immigrants may differ from the return received by natives. On the one hand, natives have an advantage in language and other countryspecific human capital. This may enable them to gain more productivity-enhancing skills from a given year of formal instruction. On the other hand, attending school in the host country may speed the assimilation process for immigrants. If, in addition to providing them with the human capital usually associated with formal education, attending school helps immigrants learn about domestic institutions and norms more rapidly and completely than they otherwise would, the return to domestic schooling might well be higher for immigrants than for natives.

A second interesting effect of domestic schooling for immigrants is that it may help them to convert their foreign human capital into terms rewarded domestically. Attending school in the host country may aid in the transferability of an immigrant's human capital, by giving him the language proficiency needed to literally translate his skills. It may also provide him with other countryspecific human capital which will enable him to better apply his previously acquired skills in the new labor market setting. Especially for immigrants who arrive with education or training that is not

5 For empirical evidence documenting occupational downgrading upon arrival and subsequent upgrading with duration of residence, see Chiswick (1978b) for the United States, and Sabatello (1979) and Flug, Kasir, and Ofer (1992) for Israel. 
very well matched to host county, attending school there may be invaluable in teaching them to use that human capital in ways rewarded in the host labor market. Such knowledge might be very difficult to obtain without further formal instruction. In terms of estimated parameters, this indirect effect of domestic schooling would be observed in a higher return to an immigrant's foreign schooling when it has been followed by schooling in the host country.

\section{Immigration to Israel and the Census of Population Data}

Israel, like the United States, is a country of immigrants. Israel continues to receive very large inflows, relative to its population. Most current immigrants are from the former Soviet Union. Earlier immigrants originated in diverse parts of the world, with the largest concentrations coming from Eastern Europe and North Africa. Immigration to Israel has been driven more by political and ideological factors than economic ones, relative to immigration to the world's major host countries, namely the United States, Canada, and Australia. In addition, the immigration of Jews to Israel is virtually unrestricted. The degree of self-selection along economic lines among immigrants to Israel is thus probably weaker than is the case for those countries. ${ }^{6}$

The data used in this study are the public-use microdata samples of the two most recent Israeli Censuses of Population and Housing, conducted in 1972 and 1983 . Following a test of the necessity of using two cross-sections of data to identify the parameters of interest, the analysis is conducted on the data from the later census. All Israeli citizens- Jews, Arabs, and others- are included in the census, which is a $1 / 5$ sample of the population. This covers virtually all residents of Israel proper, as well as citizens living in the West Bank and the Gaza Strip, who constitute $2 \%$ of the Israeli population.

\footnotetext{
${ }^{6}$ See Borjas (1987).
} 
In order to facilitate comparisons with results from the literature on immigration to the United States, which focusses primarily on male immigrants, the sample is restricted to men aged $25-65$. $^{7}$ So as not to confound the present analysis with the issue of Arab-Jewish differences in the labor market, Arabs are not included in the sample. Kibbutz and collective members, students, and the self-employed are also excluded. Finally, only full-time, salaried, nonagricultural workers reporting earnings of between 5,000 and 500,000 Israeli Shekels per month are retained. ${ }^{8}$ After these adjustments, 54,103 individuals remain in the 1983 sample.

Only one-third of these men are native-born Israelis. The foreign-born are classified into four continent-of-origin groups: Western (primarily from Western Europe and the Americas), Eastern European, Soviet, and those from Asia and Africa. The countries included under each of these headings are listed in the Appendix. Table 1 shows the breakdown of immigrants into these four groups, as well as the major countries of origin. Roughly half of the immigrants are of African or Asian descent (AA), and half are of European, American, or Soviet origin (EA). Forty-two percent are from the USSR, Morocco, or Romania, with the remainder distributed over a wide range of countries.

The mean characteristics of the 1983 sample are presented in Table 2. The average age of immigrants is 45.6 , eleven years older than the typical native. The mean immigrant came to Israel in 1956 , at age 19 , but at the time of the survey, $14.7 \%$ of Soviet immigrants had been in Israel for only five years or less. Mean monthly earnings for this sample are about $\$ 750$ (in 1983 U.S.

${ }^{7}$ For military security reasons, men between the ages of 18 and 24 are coded as age 21 in the publicuse files of the census microdata. Such censoring generates difficulties in calculating many key variables used in the analysis, such as years since migration. Men under the age of 25 are therefore excluded from the sample. Given Israel's compulsory 3-year military service, many men in this age range would not be employed in the civilian labor market in any event.

${ }^{8}$ This is equal to approximately $\$ 90-\$ 9,000$ in 1983 U.S. dollars. About $10 \%$ of the sample had zero income. Another $3 \%$ had income below 5,000 shekels and $0.1 \%$ had income over 500,000 shekels. 
dollars). Information is available in the census on hours worked per week. However, many people appear to have reported hours per month instead. Since creating an hourly wage variable might introduce more noise than signal to the data, the monthly earnings measure is used in all of the analysis below.

Table 3 contains detailed information on schooling for the five broad origin groups. The average years of completed schooling among native Israelis is 12.4 years. Educational attainment is highest for Western immigrants (14.1 years) and lowest for AA immigrants (9.4 years). More than one-third of AA immigrants have only attended primary school, while over one-third of native Israelis and $57.3 \%$ of Western immigrants have had some post-secondary education.

\section{Immigrants' Earnings and Assimilation}

It is instructive to begin the empirical analysis with a standard human capital earnings function $^{9}$ to illustrate the basic relationships in the Israeli data and compare them to the standard results obtained from data on the United States. The human capital earnings equation used is:

$$
\mathrm{y}=\beta_{0}+\beta_{1} \text { MARRIED }+\beta_{2} \operatorname{EXP}+\beta_{3} \operatorname{EXP}^{2}+\beta_{4} \mathrm{ED}+\epsilon,
$$

where $\mathrm{y}$ is log earnings, MARRIED is a dummy variable for marital status, EXP is years of potential labor market experience, ${ }^{10}$ and ED is years of schooling completed. This equation is estimated in the first column of Table 4. The measure of $y$ used as the dependent variable in this and all

${ }^{9}$ Mincer (1974).

${ }^{10}$ The standard constructed "potential labor market experience" variable - age minus education minus a constant - may be less accurate as a measure of actual labor market experience in Israel, relative to the United States, due to variations in the length of army service in Israel. 
subsequent tables is the log of monthly shekel earnings.

The results in column (1) show a premium of $20 \%$ to being married. The return to experience (evaluated at 45 years of age and 12 years of schooling) is approximately $2.2 \%$ per year. The return to schooling is about $7.8 \%$ per year. It is interesting to note that all of these coefficients are quite close to standard estimates of these parameters found in U.S. data. ${ }^{1}$ Adding industry and occupation dummies does not appreciably change any of the coefficients, except, of course, in reducing the return to schooling. In the earnings regressions that follow, no correction is made for industry or occupation. This is in order to include earnings gains associated with rising occupational status as part of the earnings growth immigrants experience as they assimilate. ${ }^{12}$

Turning to immigration, the standard equation (due to Chiswick 1978a) used to reflect the initial earnings gap between immigrants and natives and any subsequent earnings convergence with time since arrival is:

$$
\begin{aligned}
& \mathrm{y}=\beta_{0}+\beta_{1} \text { MARRIED }+\beta_{2} \text { EXP }+\beta_{3} \text { EXP }^{2}+\beta_{4} \text { ED }+\beta_{5} \mathrm{~m} \\
& +\beta_{6} \text { YRSHOST }+\beta_{7} \text { YRSHOST }^{2}+\epsilon
\end{aligned}
$$

where $\mathrm{m}$ is a dummy for immigrant status and YRSHOST is the number of years elapsed since an immigrant's arrival in the host country. Since years since arrival are held constant in this regression, the immigrant status dummy measures the earnings disadvantage, relative to an otherwise comparable native, of a newly arrived immigrant. In the absence of systematic changes in the earnings potential

\footnotetext{
${ }^{11}$ See Willis (1986).
}

${ }^{12}$ In regressions not reported here, correcting for the same set of observable characteristics as well as the ability to speak Hebrew, Israeli Arabs were found to earn approximately one-third less than Israeli Jews. This differential shrank only slightly when one-digit occupation and industry controls were added. 
of successive immigrant arrival cohorts, the YRSHOST variable captures the rate at which the immigrant-native earnings gap narrows as immigrants assimilate into the labor market.

The issue of potential "cohort quality" effects has received much attention in the literature on immigration. ${ }^{13}$ In a single cross-section of data, it is not possible to separately identify aging and cohort effects. A positive estimated effect of YRSHOST on earnings in equation (2) could therefore be due to a rise in immigrants' relative earnings with time since arrival, or to earlier immigrant arrival cohorts having permanently higher earnings potential than more recent ones.

In order to test the extent to which the cross-sectional return to YRSHOST reflects assimilation versus cohort effects, two cross-sections of data are needed. Equation (2) can then be estimated on the pooled data, with arrival-cohort dummies added to the equation. If the return to YRSHOST is invariant to the addition of the cohort dummies, then it is legitimate to interpret that coefficient as a measure of assimilation in cross-sectional analysis.

Table 5 pools data from the 1972 and 1983 Israeli Censuses of Population. ${ }^{14}$ The first column of the table presents estimates of equation (2), allowing the coefficients $\beta_{0}, \beta_{1}, \beta_{2}, \beta_{3}$, and $\beta_{4}$ to be different in the two years. ${ }^{15}$ Note that even with two cross-sections of data, in order to test for the presence of cohort effects, it is necessary to constrain the returns to immigrant status, years since arrival, and arrival cohort to be the same in both years.

In the second column of Table 5, a set of arrival-cohort dummy variables is added to the

${ }^{13}$ The issue was first raised by Borjas (1985), who concludes that most of the return to years since arrival in the United States is due to a systematic decline in the quality of successive immigrant cohorts, rather than to assimilation. See Friedberg (1992) and LaLonde and Topel (1992), among others, for reexaminations of this finding.

${ }^{14}$ The rules used in constructing the 1972 sample are the same as those used for the 1983 sample.

${ }^{15}$ An F-test of the equality of these coefficients across the two years rejects at the $1 \%$ level that they are the same. 
regression. There are 14 dummies, covering the years 1917-1983 in 5-year intervals. The coefficients on "Years in Israel" (YRSHOST) and its square are quite close in columns (1) and (2). If the same equations are run with YRSHOST entering linearly, the coefficient is 0.00836 (t-statistic of 54.4) when the arrival-cohort dummies are omitted and 0.00828 (t-statistic of 14.5) when they are included. Correcting for continent of origin in columns (3) and (4) also shows the effect of YRSHOST to be largely invariant to the inclusion of arrival-cohort effects. The linear version here yields a return to YRSHOST of 0.00845 (t-statistic of 53.9) without cohort effects and 0.00849 (t-statistic of 14.9) with them.

These results indicate that the coefficient on YRSHOST estimated in a single cross-section of data is correctly interpreted here as a measure of immigrant earnings growth over time since arrival and does not reflect a decline in the earnings potential of more recent arrival cohorts. An F-test of the joint significance of the arrival-cohort dummies rejects the null that they do not differ from zero, although with a standard deviation of 0.04 , they are rather small in size. In any case, the magnitude of the cohort effects is unimportant for the purpose of obtaining unbiased estimates of assimilation rates. All that matters is that they do not follow a systematic pattern over time. As these cohort effects do not, their omission does not bias the return to YRSHOST. The analysis can therefore proceed, using the data from the 1983 Census alone to estimate the parameters of interest.

Returning to Table 4, using the specification in equation (2), column (2) shows that, upon arrival in Israel, the average immigrant earns about one-third less than a native-born Israeli with the same observable characteristics. This earnings gap diminishes over time, but is eliminated altogether only after about 35 years. In studies of the United States, the initial earnings differential is typically estimated to be around $15-30 \%$ for immigrants taken as a whole, i.e., somewhat smaller than in 
Israel. ${ }^{16}$ There is not a consensus in the literature regarding the assimilation rate of immigrants in the United States, but most estimates fall in the range of $0-2 \%$ per year. ${ }^{17}$ The assimilation rate of immigrants to Israel is approximately $1 \%$ per year.

In column (3), earnings at arrival are allowed to differ among continent-of-origin groups, while restricting the effect of years since arrival to be the same for all groups. This yields the result that among immigrants, holding schooling and experience constant, Westerners earn $31.8 \%$ less than natives upon arrival, East-European immigrants - 36.5\% less, Soviet immigrants $-35.7 \%$ less, and Asian and African immigrants - $49.7 \%$ less.

When the effect of years since immigration is allowed to vary by origin as well, the result is the set of relative earnings profiles plotted in Figure 1 (taken from column (4) of Table 4). Westerners start out at the highest level of all immigrant groups, with East-European and Soviet immigrants earning relatively less. Over time, these three groups roughly converge, with Asian and African immigrants lagging far behind. The fact that the first three groups actually overtake natives after 19-24 years could simply be an artifact of ethnic differences persisting within the native population $^{18}$ (i.e., if white immigrants in the United States eventually just reached parity with white natives, we would still observe them overtaking the native-born U.S. population taken as a whole because minorities are included in the latter group but not the former). In addition, the great majority of immigrants have fewer years since immigration than the post-takeover point, so that this portion of the profile is largely out-of-sample prediction.

${ }^{16}$ This is consistent with the greater representation of refugees among immigrants to Israel. See Chiswick (1979) for a discussion of refugee assimilation patterns.

${ }^{17}$ Borjas (1985) and (1990) finds assimilation rates at the lower end of this range, as do Baker and Benjamin (1994) in their study of Canada. Chiswick (1978), Friedberg (1992), and LaLonde and Topel (1992) estimate assimilation rates at the upper end of this range.

${ }^{18}$ See Ben-Porath (1986) and Amir (1988). 


\section{Returns to Schooling}

Having established the basic stylized facts concerning the relative earnings of immigrants in Israel, the focus shifts to the relative returns to schooling received by immigrants and natives and - for immigrants - to schooling acquired in Israel as opposed to schooling acquired abroad.

The measure of an individual's level of education used here is the number of completed years of schooling. ${ }^{19}$ To construct measures of the years of schooling completed in the country of origin and in Israel, it is assumed that children start school at the age of seven and attend continuously until completing their total years of schooling. Since the age at which an immigrant arrived in Israel is known, one can calculate the years of schooling that would have been completed before and after his move to Israel..$^{20}$ The resulting mean years of schooling in Israel and abroad are shown in the upper panel of Table 3. Just under half of all immigrants have attended school in Israel. The average fraction of schooling acquired abroad is $65 \%$. This fraction is lowest for AA immigrants (55\%) and highest for Soviet immigrants $(86 \%)$, only one-fifth of whom have attended school in Israel at all.

${ }^{19}$ Observations for which the last type of schooling was post-secondary yeshiva (religious academy) are excluded from the sample. This is because religious Jews often continue to study at such institutions throughout their lives. Attending a post-secondary yeshiva is better classified as a religious activity than as a program of human capital accumulation applicable in the labor market. Thus, including in the sample individuals who count years spent at a yeshiva in their total years of schooling would bias the coefficient on standard schooling downward. Also excluded are the small number of other people in the sample who report over 27 years of schooling.

${ }^{20}$ For an individual with a discontinuous schooling history who temporarily suspended his education while still in his country of origin, this method will overstate the number of years acquired abroad. The bias will be greater, the longer an individual was out of school between schooling spells abroad or- if he did not return to school abroad at all following the interruption- the longer he was out of school before migrating. To test the accuracy of this imputation technique, I applied it to data from the U.S. Survey of Income and Education, a dataset which also contains direct information on years of schooling completed abroad. The correlation between the true and imputed measures of origin-country schooling was .78 . 
a. The return to schooling for immigrants

Let $\mathrm{ED}_{\mathrm{i}}$ and $\mathrm{EXP}_{\mathrm{i}}$ denote years of schooling and potential labor market experience obtained in country $i$, where $i=1$ for the country of origin and $i=2$ for Israel. ${ }^{21}$ Then for immigrants:

$$
\text { YRSHOST }=\mathrm{EXP}_{2}+\mathrm{ED}_{2}+\mathrm{k}
$$

where $\mathrm{k}=\max (0,6$-age + YRSHOST $)$, so that $\mathrm{k}$ equals 0 for the $81 \%$ of immigrants who migrated after the age of 6 , and $\mathrm{k}$ equals between 1 and 6 for the others. By putting YRSHOST on the righthand-side of the earnings equation, equation (2) imposes the constraint that the native-immigrant difference in the returns to $\mathrm{EXP}_{2}$ and $\mathrm{ED}_{2}$ must be equal. Although this is the standard specification used in the literature, the data strongly reject this restriction. The constraint can be relaxed by using a slightly different specification, which replaces YRSHOST with $\operatorname{EXP}_{2}+\mathrm{ED}_{2}$. This less-restrictive equation can be specified in two empirically equivalent ways:

$$
\begin{gathered}
\mathrm{y}=\beta_{0}+\beta_{1} \text { MARRIED }+\beta_{2} \mathrm{EXP}+\beta_{3} \mathrm{EXP}^{2}+\beta_{4} \mathrm{~m}+\beta_{5}\left(\mathrm{~m} \cdot \mathrm{EXP}_{2}\right)+ \\
\beta_{6} \mathrm{ED}+\beta_{7}(\mathrm{~m} \cdot \mathrm{ED})+\beta_{8} \mathrm{ED}_{1}+\epsilon \\
\mathrm{y}=\beta_{0}+\beta_{1} \text { MARRIED }+\beta_{2} \mathrm{EXP}+\beta_{3} \mathrm{EXP}^{2}+\beta_{4} \mathrm{~m}+\beta_{5}\left(\mathrm{~m} \cdot \mathrm{EXP}_{2}\right)+ \\
\alpha_{1}\left[(1-\mathrm{m}) \cdot \mathrm{ED}_{2}\right]+\alpha_{2}\left(\mathrm{~m} \cdot \mathrm{ED}_{2}\right)+\alpha_{3} \mathrm{ED}_{1}+\epsilon .
\end{gathered}
$$

${ }^{21}$ By construction, $\mathrm{ED}_{1}=0$ and $\mathrm{EXP}_{1}=0$ for natives. While it is true that some native-born Israelis may have attended school or worked abroad, there is no information available on this in the Census data. The return to $\mathrm{ED}_{1}$ and $\mathrm{EXP}_{1}$ will therefore measure the return to foreign schooling and experience for immigrants only. 
Estimates of equation (4a) appear in Table 6. In part A of the table, all immigrant groups are constrained to have the same coefficients. The estimated return to schooling in Israel is $9.4 \%$ for natives and $8.5 \%$ for immigrants. This result casts doubt on the hypothesis put forward earlier that immigrants might in fact gain more productive potential from an incremental year of Israeli schooling than would the native-born. The fact that natives receive a higher return may indicate that their country-specific skills, including their superior fluency in Hebrew, enable them to extract more from a year of school than can immigrants.

The negative coefficient on years of foreign schooling indicates that education received abroad is of significantly less value in the Israeli labor market than education received in Israel. Foreign schooling earns a $7.1 \%$ return, a full 1.4 percentage points less than the schooling immigrants acquire in Israel..$^{22}$

In the standard specification of the immigrant earnings equation shown in column (2) of Table 4, immigrants were found to earn about one-third less than natives upon arrival. Once the return to education is allowed to differ for immigrants and natives and for foreign and domestic schooling, the immigrant-native earnings gap becomes insignificant. This is seen in the change in the value of the estimated coefficient on the immigrant dummy variable (m) across the specifications used in Tables 4 and 6A (equations 2 and 4a, respectively). In Table 4, the coefficient on the immigrant dummy is large, negative and significant (-0.342 with a t-statistic of -28.8). In Table 6A, the point estimate is small, positive, and insignificant ( 0.0197 with a t-statistic of 1.1$)$. The lower earnings of immigrants, relative to the native-born, can therefore be fully explained by the lower

${ }^{22}$ Using the 1970 U.S. Census, Chiswick (1978a) finds that the return to schooling obtained abroad is 1 percentage point higher than the return to U.S. schooling. These results may be affected by the difficulty of imputing accurate measures of pre- and post-migration schooling in this data, in which years since migration are reported in 5- and 10-year bracketed intervals. 
value placed on their education.

The results of estimating this earnings equation separately for each of the five continent-oforigin groups are shown in Table 6B. Western and Soviet immigrants receive the highest return to Israeli schooling, and Asian and African immigrants receive the lowest, at $6.5 \%$. The return received by natives $(9.9 \%)$ is again significantly higher than that of any of the immigrant groups.

Regardless of origin group, the return to country-of-origin education is lower than the return to Israeli education, i.e., human capital is only partially portable. The return to country-of-origin schooling is $6.9 \%$ for Western immigrants, somewhat lower for Soviet and East-European immigrants, and only $5.7 \%$ for AA immigrants. While this pattern supports the idea that EA school quality is higher and better matched to the Israeli labor market than is AA schooling, these results could equally well reflect less discrimination between EA and AA immigrant workers at lower levels of education than at higher levels.

\section{b. Raising the return to origin-country schooling}

Having established that the lower value placed on immigrants' education fully explains their earnings disadvantage relative to natives with the same observable characteristics, a natural question is whether this difference is fixed or whether there exist factors which can reduce or eliminate it. This section studies three factors which might raise the return to foreign schooling.

Equation (4b) is modified by the addition of four variables: NOHEB (a dummy variable which equals 1 for immigrants who do not speak Hebrew) and the interaction of $\mathrm{ED}_{1}$ with $\mathrm{EXP}_{2}, \mathrm{ED}_{2}$, and NOHEB: 


$$
\begin{aligned}
\mathrm{y}=\beta_{0} \text { MARRIED }+\beta_{1} \mathrm{EXP}+\beta_{2} \mathrm{EXP}^{2}+\beta_{3} \mathrm{~m}+\beta_{4}\left(\mathrm{~m} \cdot \mathrm{EXP}_{2}\right)+ \\
\beta_{5}\left((1-\mathrm{m}) \cdot \mathrm{ED}_{2}\right)+\beta_{6}\left(\mathrm{~m} \cdot \mathrm{ED}_{2}\right)+\beta_{7} \mathrm{ED}_{1}+\beta_{8} \mathrm{NOHEB}+ \\
\beta_{9}\left(\mathrm{ED}_{1} \cdot \mathrm{EXP}_{2}\right)+\beta_{10}\left(\mathrm{ED}_{1} \cdot \mathrm{ED}_{2}\right)+\beta_{11}\left(\mathrm{ED}_{1} \cdot \mathrm{NOHEB}\right)+\epsilon .
\end{aligned}
$$

The first factor considered is Hebrew language proficiency. ${ }^{23}$ One reason why immigrants' skills are not highly valued in Israel may simply be that many immigrants lack the language proficiency needed to make productive use of their human capital. A well-trained surgeon who cannot communicate in Hebrew cannot practice medicine in Israel. Most jobs that require a high level of training also require a relatively high degree of literacy and speaking ability. It is reasonable to imagine that immigrants who lack rudimentary language skills will be confined to menial jobs, which do not require them.

When NOHEB is added to the specification of equation (4b), the estimated coefficient is -0.14 (with a t-statistic of -10.8 ), indicating that immigrants who lack Hebrew language skills are at a considerable disadvantage relative to other immigrants.

To ascertain whether language proficiency affects more- and less-educated immigrants differently, in Table 7 , which estimates equation 5 , NOHEB is interacted with education obtained abroad. The result is a strong negative interaction. The coefficient on NOHEB becomes positive when the interaction term is introduced (possibly due to a nonlinearity in this interaction), but the net effect of NOHEB is negative for the $90 \%$ of non-Hebrew-speaking immigrants who have more than two years of schooling abroad. The rise in the return to foreign schooling associated with some knowledge of Hebrew is 2.2 percentage points per year of schooling. Thus, Hebrew language ability

${ }^{23}$ There is a large body of evidence demonstrating the importance of language fluency for earnings. See McManus, Gould, and Welch (1983), Kossoudji (1988), Chiswick (1991), Chiswick and Miller (1992), Bloom and Grenier (1992), and Beenstock (1993). 
considerably raises the return to schooling obtained abroad, but it cannot eliminate the gap between the returns to foreign and domestic education.

Apart from Hebrew language proficiency, other factors may contribute to a compression of skill differentials among newly arrived immigrants. Lacking many types of country-specific human capital, both highly skilled and less skilled immigrants are constrained to take jobs in less-skilled occupations upon arrival. As they accumulate work experience in Israel, immigrants gain much country-specific knowledge, including information about the availability of suitable jobs. As with any new entrants to the labor market, immigrants search for jobs that best match their skills. In addition, through work experience they may learn how to apply their skills and training in Israel more effectively. A simple example would be a restaurateur who must first work as a waiter, in order to learn about licensing, equipment suppliers, advertising, etc. in Israel before being able to open his own establishment. These processes of search and learning would explain the greater estimated return to experience for immigrants than for natives. For highly educated immigrants, we would expect this earnings growth to be even greater than for less educated immigrants, because the gap between their initial and potential occupational standing is greater.

An initial compression and subsequent divergence of skill differentials would be reflected in a rise in the return to origin-country schooling with labor market experience in Israel. Equivalently, the assimilation rate of better-educated immigrants would be found to be higher than that of their less-educated counterparts.

For immigrants taken as a whole, the interaction between foreign education and experience in Israel is insignificant in Table 7. Looking across the different immigrant groups, it is apparent that this is so because the effect exists only for certain continent-of-origin groups. The return to foreign schooling rises with experience in Israel for Western and Soviet immigrants, but is unaffected 
by domestic experience for others. Even for the former groups, the effect is small, resulting at most in a 0.5 percentage point rise for every 10 years of experience.

Finally, a more effective way for immigrants to gain the skills necessary to adapt their previously acquired training to Israel may be by obtaining further formal education after arrival. The interaction of foreign and Israeli schooling enters positively and significantly in the earnings equation in column (1) of Table 7, meaning that immigrants who attend school in Israel earn a higher return on their country-of-origin human capital than immigrants who completed their education abroad. For the average immigrant, who has completed 3.7 years of schooling in Israel, this interaction raises the average return to origin-source education to $7.6 \%$, eliminating half of the gap between the returns to foreign and Israeli schooling. For AA immigrants, there is a large rise in the return to foreign schooling resulting from acquiring further education in Israel. Just three years of schooling in Israel completely eliminate the difference in the return to foreign schooling and the return to Israeli schooling.

As argued earlier, Israeli training may enable an immigrant to translate the human capital he brought with him to Israel into terms valued in the Israeli labor market. It is therefore not surprising that AA immigrants benefit the most from this indirect effect of domestic schooling, since, among immigrant groups, their country-of-origin education is initially least valued in the Israeli economy. East-European immigrants also experience an increase in the return to their source-country education following schooling in Israel, but the effect for this group is smaller. For Western immigrants, there is a puzzling negative effect of having attended school in Israel on the return to education acquired abroad. It is unclear what lies behind this anomaly.

These results are consistent with a model in which acquiring further education raises the return to schooling obtained abroad. It should be noted, however, that this pattern may also reflect 
positive self-selection on the part of individuals who choose to get further schooling after immigration. Unfortunately, it is impossible to distinguish between these two effects using the available data.

\section{c. Differences by type of schooling}

Some of the results in the last section, such as the lower return to foreign education than to Israeli education, may simply be artifacts of the assumption of linearity in the return to schooling. Since immigrants' foreign education precedes their Israeli education, education in Israel necessarily take place at a higher level of total years of schooling. If there are decreasing returns to schooling, the estimated return to Israeli schooling for immigrants, following the methodology in the previous section, will be downward biased. In this section, the return to schooling is allowed to vary with its level. In addition, the transferability of human capital should depend on the type of human capital. For example, higher levels of education may be more country-specific than the basic skills learned in primary school.

To analyze this question, years of education are divided into three categories: primary school (years 1-8), secondary (years $9-12$ ), and post-secondary school $(13+)$. The return to education is then estimated as a piecewise linear function. Equation (6) modifies equation (4a) by replacing the uniform years of schooling variables ed $\mathrm{d}_{\mathrm{i}}$ with years of schooling in each of the six categories, $\mathrm{ED}_{\mathrm{ji}}$, where $\mathrm{j}=\mathrm{p}, \mathrm{h}, \mathrm{c}$ indicates primary, secondary, and post-secondary, respectively, and $\mathrm{i}=1,2$ indicates source country. ${ }^{24}$

\footnotetext{
${ }^{24} \mathrm{p}$ for "primary", $\mathrm{h}$ for "high school", and $\mathrm{c}$ for "college", although it should be noted that the "college" category includes all types of post-secondary schooling.
} 


$$
\begin{aligned}
\mathrm{y}=\beta_{0} & +\beta_{1} \text { MARRIED }+\beta_{2} \operatorname{EXP}+\beta_{3} \mathrm{EXP}^{2}+\beta_{4} \mathrm{~m}+\beta_{5}\left(\mathrm{~m} \cdot \mathrm{EXP}_{2}\right) \\
& +\beta_{6} \mathrm{ED}_{\mathrm{p}}+\beta_{7} \mathrm{ED}_{\mathrm{h}}+\beta_{8} \mathrm{ED}_{\mathrm{c}}+\beta_{9}\left(\mathrm{~m} \cdot \mathrm{ED}_{\mathrm{p}}\right)+\beta_{10}\left(\mathrm{~m} \cdot \mathrm{ED}_{\mathrm{h}}\right) \\
& +\beta_{11}\left(\mathrm{~m} \cdot \mathrm{ED}_{\mathrm{c}}\right)+\beta_{12} \mathrm{ED}_{\mathrm{p} 1}+\beta_{13} \mathrm{ED}_{\mathrm{h} 1}+\beta_{14} \mathrm{ED}_{\mathrm{c} 1}+\epsilon .
\end{aligned}
$$

Estimates of this equation can be found in Table 8. The results in column (1), which runs this regression for natives only, reveal that the return to schooling is indeed strongly nonlinear. The return to a year of primary school is $3.2 \%$, to a year of high school $-13.3 \%$, and to a year of postsecondary school $-8.7 \%$. The pattern is the same for immigrants.

Turning to the difference in the returns to schooling acquired abroad and in Israel, some interesting patterns emerge. First, primary school equally valued, regardless of where it was acquired. This is seen in the insignificant coefficients on the variable "primary abroad". The one exception is AA-source primary school, which yields a very slightly lower return. In general, the skills embodied in primary schooling seem to be quite portable across national boundaries. The results at the secondary school level are quite different. The Israeli labor market places a large premium on acquiring high school training in Israel rather than abroad. This is true for all areas of origin, with an average difference of 2.8 percentage points in the rates of return per year. Finally, the differential associated with attending post-secondary school abroad rather than in Israel is smaller than that differential at the high school level. This is somewhat surprising, given that post-secondary education is generally considered to be more specialized than secondary education, suggesting that it would be less internationally portable. This pattern is probably due to the high quality of postsecondary schooling in many areas. Western, East-European, and Israeli post-secondary schooling are equally valued. Soviet post-secondary schooling earns a somewhat higher return, and AA postsecondary schooling earns a much lower return. 
d. Differences by configuration of schooling level and source

A final issue concerns the possibility that the return to schooling depends on the particular configuration of schooling obtained. For example, a year of university study in Israel may yield a different return, depending on whether the high school education that preceded it was acquired in Israel or abroad.

A set of indicator variables is constructed for different combinations of schooling levels and sources. For each individual, it is determined whether he attended primary school, secondary school, and post-secondary school, and if so, whether the given school level was acquired abroad or in Israel. ${ }^{25}$ This yields six dummy variables:

1) Attended primary school abroad.

2) Attended primary school in Israel.

3) Attended secondary school abroad.

4) Attended secondary school in Israel.

5) Attended post-secondary school abroad.

6) Attended post-secondary school in Israel.

The sample means for these attainment variables are presented in the second to bottom panel of Table 3. These variables then enter into the calculation of the nine indicator variables used in the regressions below. The three letters in the variable name denote primary school, high school, and post-secondary school, respectively. An "I" signifies that this schooling took place in Israel, an "F" signifies that it took place abroad, and " $\mathrm{O}$ " means that this level was not attained. The nine dummy

${ }^{25}$ For people who completed part of a schooling level in each country, three alternative methods of assigning that schooling to a country were used: according to where the majority of schooling at that level took place, as foreign if any of it took place abroad, or as Israeli if any of it took place in Israel. The results using these different measures being quite similar, results are presented only for the first method. 
variables are:

III - Primary, secondary, and post-secondary all acquired in Israel.

IIO - Primary and secondary in Israel, no post-secondary.

IOO - Primary in Israel, no secondary or post-secondary.

FFF - Primary, secondary, and post-secondary all obtained abroad.

FFo - Primary and secondary abroad, no post-secondary.

FOO - Primary abroad, no secondary or post-secondary.

FFI - Primary and secondary abroad, post-secondary in Israel.

FII - Primary abroad, secondary and post-secondary in Israel.

FIO - Primary abroad, secondary in Israel, no post-secondary.

The sample means for these different schooling combinations are presented in the bottom panel of Table 3. Replacing the continuous years of schooling measures used in equation (4a) with these nine schooling configuration dummies:

$$
\begin{aligned}
\mathrm{y}= & \beta_{0}+\beta_{1} \text { MARRIED }+\beta_{2} \mathrm{EXP}+\beta_{3} \mathrm{EXP}^{2}+\beta_{4} \mathrm{~m}+\beta_{5}\left(\mathrm{~m} \cdot \mathrm{EXP}_{2}\right) \\
& +\beta_{6} \mathrm{III}+\beta_{7} \mathrm{IIO}+\beta_{8} \mathrm{IOO}+\beta_{9}(\mathrm{~m} \cdot \mathrm{III})+\beta_{10}(\mathrm{~m} \cdot \mathrm{IIO})+\beta_{11}(\mathrm{~m} \cdot \mathrm{IOO}) \\
& +\beta_{12} \mathrm{FFF}+\beta_{13} \mathrm{FFO}+\beta_{14} \mathrm{FOO}+\beta_{15} \mathrm{FFI}+\beta_{16} \mathrm{FII}+\beta_{17} \mathrm{FIO}+\epsilon .
\end{aligned}
$$

Regressions of this form are presented in Table 9. Since the constant term and the returns to demographic variables vary somewhat across groups, direct comparisons cannot be made between the returns to a given configuration for two continent-of-origin groups merely by comparing their corresponding coefficients. Direct comparisons can be made, however, for the difference between two groups in the difference between two schooling configurations (i.e., comparing the difference 
between III and FFF for Western immigrants versus that difference for Soviets).

These differences in differences are presented in Table 10. It is instructive to focus on three comparisons: (1) the return to attending school in Israel for natives versus immigrants, when both groups acquired their previous education in Israel. (2) The return to attending school in Israel for natives versus immigrants, when the immigrants acquired their previous education abroad. (3) The return to Israeli versus foreign schooling for immigrants.

The return to attending school in Israel for natives versus immigrants, when both groups obtained their previous education in Israel, can be seen in first two lines of Table 10 . The college-high-school differential (III-IIO) is slightly smaller for the four immigrant groups than it is for natives. The high-school-primary-school differential (IIO-IOO) varies considerably by group, with Western and Soviet immigrants gaining much more than natives and AA immigrants gaining much less. Among immigrants who received no schooling abroad (i.e., those who immigrated too young), the returns to college are only slightly lower than the return for natives, while for high school, some immigrant groups actually earn a higher return.

The second set of comparisons is of the return to attending school in Israel for immigrants versus natives, when the immigrants obtained their previous education abroad. One case is the difference in the return to post-secondary school in Israel for a high school educated native (III-IIO) and the return for immigrant who attended high school abroad (FFI-FFO). The difference for natives is 0.5140 , or $67.2 \% .{ }^{26}$ As shown in the bottom line of the table, this increment is much lower for immigrants $(0.4676$ or $59.6 \%$ ). The same comparison at the high school level (IIO-IOO versus FIO-FOO) yields a similar result (44.7\% and $39.5 \%$ ). In both cases, immigrants receive a much lower return than do natives. Contrasting this with the previous set of comparisons suggests that one

$$
{ }^{26} \ln (\mathrm{III})-\ln (\mathrm{IIO})=0.5140 \text {, so } \mathrm{III} / \mathrm{HIO}=\mathrm{e}^{0.5140}=1.672 \text {. }
$$


of the main reasons immigrants earn a lower return to Israeli schooling than do natives is that they are building on a base of foreign schooling, rather than one of Israeli schooling.

The third set of comparisons is of the return to Israeli versus continent-of-origin schooling for immigrants. The difference in earnings for someone who attended school through the post-secondary level in Israel versus abroad is (III-FFF). This difference is positive for all immigrant groups (12.9\% on average). The difference for individuals who terminated their education at the the high school level (IIO-FFO) is also positive in all cases (6.5\% on average). Examining immigrants with foreign schooling who completed their education in Israel versus those who completed it abroad yields a similar pattern. For example, the value of attending post-secondary school in Israel versus abroad (FFI-FFF) is positive for almost all immigrant groups $(3.7 \%$ on average). The exception is Westerners, whose post-secondary schooling is more highly valued. Looking at this comparison at the high school level (FIO-FFO) also shows positive values for all groups, ranging from $3.8 \%$ for African and Asian immigrants to $10.5 \%$ for Westerners, whose origin-source education is always highly valued.

\section{Conclusions}

This paper studies the labor market assimilation of immigrants, focussing on the source of the immigrants' human capital. Human capital is found to be imperfectly portable across countries. In particular, the national origin of an individual's education is a crucial determinant of its value in the labor market. Estimation of the basic earnings determination and immigrant assimilation equations yields patterns similar to those found in the literature on the United States, suggesting that the evidence from Israel may be used to shed light on this set of questions more generally.

Upon arrival, immigrants to Israel earn approximately one-third less than their native 
counterparts of comparable measured skill levels. This gap can be fully attributed to the significantly lower value placed on the immigrants' education. With few exceptions, education acquired abroad receives a lower return in the host labor market than education acquired domestically. The return to education obtained abroad is higher for immigrants from Europe and the Western Hemisphere than for immigrants from Asia and Africa. These patterns may reflect differences in school quality across continents of origin, as well as the compatibility of the education obtained abroad with the requirements of the host labor market. They may also reflect a lesser degree of discrimination against immigrant workers from Asia or Africa at low levels of education than at high levels.

The direct return to a year of schooling obtained in the host country is also found to be higher for natives than for immigrants. One explanation for this result is that natives' superior language proficiency and other country-specific knowledge enable them to learn more productively than immigrants.

The portability of education is found to vary significantly with its level. Primary school is equally valued, almost regardless of where it was acquired. The source of a high school education, however, is an important determinant of its value, with domestic high school earning the highest return. The return to post-secondary schooling obtained abroad varies greatly with continent of origin.

Finally, three factors are found to be associated with a higher return to education acquired abroad. First, immigrants proficient in Hebrew earn a higher return than immigrants with weak language skills. Second, for Western and Soviet immigrants, the return to origin-country schooling rises with the accumulation of host-country work experience. Equivalently, the more highly educated immigrants in these groups experience more earnings growth over time than do their less educated counterparts. The faster assimilation rate of the more educated immigrants somewhat offsets their 
larger initial earnings deficit relative to comparably educated natives. Third, education obtained in the destination country appears to significantly raise the return to schooling acquired abroad for Asian and African immigrants, with weaker effects for European and American immigrants.

These three findings are consistent with a model in which destination-country human capital enables immigrants to translate the skills they accumulated in their countries of origin into terms rewarded in the host labor market. This suggests a compound benefit of policies which encourage immigrants to obtain language and other training. 


\section{Appendix}

\section{Continent of Origin Groups}

\section{West}

Argentina, Australia, Austria, Belgium, Bolivia, Brazil, Canada, Chile, Colombia, Cuba, Denmark, Ecuador, Finland, France, Germany, Holland, Ireland, Italy, Luxembourg, Mexico, New Zealand, Norway, Panama, Peru, Portugal, South Africa, Spain, Sweden, Switzerland, United Kingdom, United States, Uruguay, Venezuela, Zimbabwe (Rhodesia); unspecified Central America, South America, Europe, and Oceania.

\section{Eastern Europe}

Albania, Bulgaria, Czechoslovakia, Greece, Hungary, Poland, Romania, Yugoslavia.

\section{Soviet Union}

Soviet Union.

\section{Asia-Africa}

Afghanistan, Algeria, Burma, China, Cyprus, Egypt, Ethiopia, Eritrea, India, Indonesia, Iran, Iraq, Japan, Jordan, Korea, Lebanon, Libya, Mongolia, Morocco, Pakistan, Philippines, Saudi Arabia, Somalia, South Yemen, Sudan, Syria, Tangier, Tunisia, Turkey, Yemen; unspecified Africa, unspecified Asia. 
Table 1. Area of Origin

1) Percent of Immigrants by Continent:

$\begin{array}{lr}\text { Western Hemisphere and Western Europe } & 9.01 \\ \text { Eastern Europe } & 29.26 \\ \text { USSR } & 12.88 \\ \text { Asia and Africa } & 48.85\end{array}$

2) Percent of Immigrants by Most Common Countries:

$\begin{array}{lr}\text { USSR } & 12.88 \\ \text { Morocco } & 14.65 \\ \text { Romania } & 14.29 \\ \text { Iraq } & 8.79 \\ \text { Poland } & 8.72 \\ \text { Iran } & 3.72 \\ \text { Yemen } & 3.63 \\ \text { Turkey } & 3.59 \\ \text { Egypt/Sudan } & 2.81 \\ \text { Tunisia } & 2.34 \\ \text { Bulgaria } & 2.28 \\ \text { Germany } & 2.26 \\ \text { Libya } & 1.85 \\ \text { India/Pakistan } & 1.59 \\ \text { Argentina } & 1.36 \\ \text { Hungary } & 1.31 \\ \text { Czechoslovakia } & 1.23 \\ \text { USA } & 1.04\end{array}$

Source: Author's tabulation of the 1983 Israeli Census of Population microdata. 
Table 2. Summary Statistics

\begin{tabular}{lcccccc}
\hline & Native & $\begin{array}{c}\text { Immi- } \\
\text { grant }\end{array}$ & West & $\begin{array}{c}\text { E. } \\
\text { Europe }\end{array}$ & USSR & $\begin{array}{c}\text { Asia- } \\
\text { Africa }\end{array}$ \\
\hline Age & 34.8 & 45.6 & 44.2 & 49.8 & 44.3 & 43.7 \\
& $(8.6)$ & $(10.9)$ & $(10.8)$ & $(10.6)$ & $(11.5)$ & $(10.1)$ \\
Year of & & 1956 & 1958 & 1953 & 1968 & 1955 \\
immigration & & $(11.0)$ & $(14.6)$ & $(9.9)$ & $(12.2)$ & $(8.0)$ \\
Weeks worked per & 50.5 & 51.0 & 50.2 & 51.3 & 51.2 & 50.9 \\
year & $(8.1)$ & $(7.3)$ & $(7.3)$ & $(6.3)$ & $(7.0)$ & $(7.8)$ \\
Hours worked per & 48.9 & 47.9 & 48.4 & 48.1 & 47.5 & 47.8 \\
week & $(6.5)$ & $(5.8)$ & $(6.5)$ & $(6.0)$ & $(5.5)$ & $(5.6)$ \\
& & & & & & \\
$\begin{array}{l}\text { Gross monthly } \\
\text { income (1983 }\end{array}$ & 44,796 & 41,505 & 55,593 & 48,270 & 41,294 & 34,910 \\
Israeli Shekels) & $(32,056)$ & $(29,754)$ & $(37,737)$ & $(33,000)$ & $(29,014)$ & $(23,833)$ \\
Married (\%) & 85.5 & 93.2 & 91.9 & 93.2 & 93.6 & 93.4 \\
$\begin{array}{l}\text { Don't speak } \\
\text { Hebrew (\%) }\end{array}$ & & 4.7 & 4.6 & 4.0 & 15.4 & 2.4 \\
Years since & & & & & & \\
immigration & & 26.9 & 25.3 & 30.0 & 15.1 & 28.5 \\
$\begin{array}{l}\text { Years since img. } \\
\text { < 5 (\%) }\end{array}$ & & $(11.0)$ & $(14.6)$ & $(9.9)$ & $(12.2)$ & $(8.0)$ \\
$\begin{array}{l}\text { Age at } \\
\text { immigration }\end{array}$ & 3.7 & 9.1 & 1.1 & 14.7 & 1.2 \\
Sample size & & 18.7 & 18.9 & 19.8 & 29.1 & 15.2 \\
\hline
\end{tabular}

Note: Figures are means for the sample of full-time, salaried, non-agricultural male workers aged 25-65 in the 1983 Israeli Census of Population. Standard deviations are in parentheses. 
Table 3. Schooling Characteristics

\begin{tabular}{|c|c|c|c|c|c|c|}
\hline & Native & Immigrant & West & E. Europe & USSR & $\begin{array}{l}\text { Asia- } \\
\text { Africa }\end{array}$ \\
\hline \multicolumn{7}{|l|}{ Years of schooling } \\
\hline In Israel & $\begin{array}{l}12.4 \\
(3.3)\end{array}$ & $\begin{array}{c}3.7 \\
(5.1)\end{array}$ & $\begin{array}{l}4.8 \\
(6.1)\end{array}$ & $\begin{array}{c}3.6 \\
(5.3)\end{array}$ & $\begin{array}{c}1.7 \\
(4.0)\end{array}$ & $\begin{array}{c}4.1 \\
(4.8)\end{array}$ \\
\hline Abroad & & $\begin{array}{c}7.0 \\
(5.4)\end{array}$ & $\begin{array}{l}9.2 \\
(6.9)\end{array}$ & $\begin{array}{c}7.9 \\
(5.0)\end{array}$ & $\begin{array}{l}10.3 \\
(5.0)\end{array}$ & $\begin{array}{c}5.2 \\
(4.6)\end{array}$ \\
\hline Total & $\begin{array}{l}12.4 \\
(3.3)\end{array}$ & $\begin{array}{l}10.8 \\
(4.2)\end{array}$ & $\begin{array}{l}14.1 \\
(3.9)\end{array}$ & $\begin{array}{l}11.5 \\
(3.9)\end{array}$ & $\begin{array}{l}12.0 \\
(4.0)\end{array}$ & $\begin{array}{c}9.4 \\
(3.9)\end{array}$ \\
\hline $\begin{array}{l}\text { Terminated Education } \\
\text { in Israel (\%) }\end{array}$ & & 46.3 & 51.6 & 42.7 & 21.3 & 54.1 \\
\hline \multicolumn{7}{|c|}{ Highest level attained (\%) } \\
\hline Primary & 12.8 & 27.4 & 7.7 & 24.8 & 18.7 & 34.9 \\
\hline Secondary & 51.0 & 41.4 & 34.4 & 40.8 & 35.9 & 44.6 \\
\hline Post-Secondary & 35.9 & 27.3 & 57.3 & 33.4 & 43.7 & 13.8 \\
\hline \multicolumn{7}{|c|}{ Whether level attained and source (\%) } \\
\hline Primary $=F$ & & 67.9 & 69.2 & 76.7 & 88.0 & 57.1 \\
\hline Primary $=\mathbf{I}$ & 99.7 & 28.4 & 30.3 & 22.4 & 10.3 & 36.3 \\
\hline Secondary $=F$ & & 35.2 & 52.6 & 40.1 & 63.8 & 21.5 \\
\hline Secondary $=1$ & 86.9 & 33.6 & 39.1 & 34.1 & 15.8 & 36.8 \\
\hline Post-Secondary $=F$ & & 13.3 & 31.7 & 14.1 & 33.5 & 4.1 \\
\hline Post-Secondary $=I$ & 35.9 & 14.0 & 25.6 & 19.3 & 10.2 & 9.6 \\
\hline III & 35.9 & 7.5 & 15.0 & 10.1 & 4.4 & 5.4 \\
\hline IIO & 51.0 & 14.3 & 13.0 & 10.0 & 4.7 & 19.6 \\
\hline 100 & 12.8 & 6.4 & 2.2 & 2.1 & 1.1 & 11.2 \\
\hline FFF & & 13.3 & 31.7 & 14.1 & 33.5 & 24.1 \\
\hline FFO & & 19.3 & 15.4 & 22.7 & 27.7 & 15.8 \\
\hline FOO & & 21.0 & 5.5 & 22.7 & 17.5 & 23.7 \\
\hline FFI & & 2.5 & 5.4 & 3.2 & 2.5 & 1.6 \\
\hline FII & & 3.9 & 5.0 & 5.9 & 3.2 & 2.6 \\
\hline FIO & & 7.7 & 5.9 & 7.9 & 3.4 & 9.1 \\
\hline $\mathrm{OOO}$ & 0.3 & 3.6 & 0.3 & 0.7 & 1.4 & 6.5 \\
\hline
\end{tabular}

Note: Standard deviations are in parentheses. "Primary $=\mathrm{I}$ " is a dummy variable, indicating that primary schooling was completed in Israel; "Primary $=F$ " indicates that primary schooling was completed abroad. The three letter combinations (FIO, etc.) are indicator variables to be interpreted as follows: The first letter indicates the location of primary school, the second the location of secondary school, and the third the location of post-secondary school. $\mathrm{F}$ indicates foreign, $\mathrm{I}$ indicates Israel, and $\mathrm{O}$ indicates none. Thus "FIO" indicates having attended primary school abroad, secondary school in Israel, and no post-secondary school. 
Table 4. Immigrant Status and Earnings Convergence

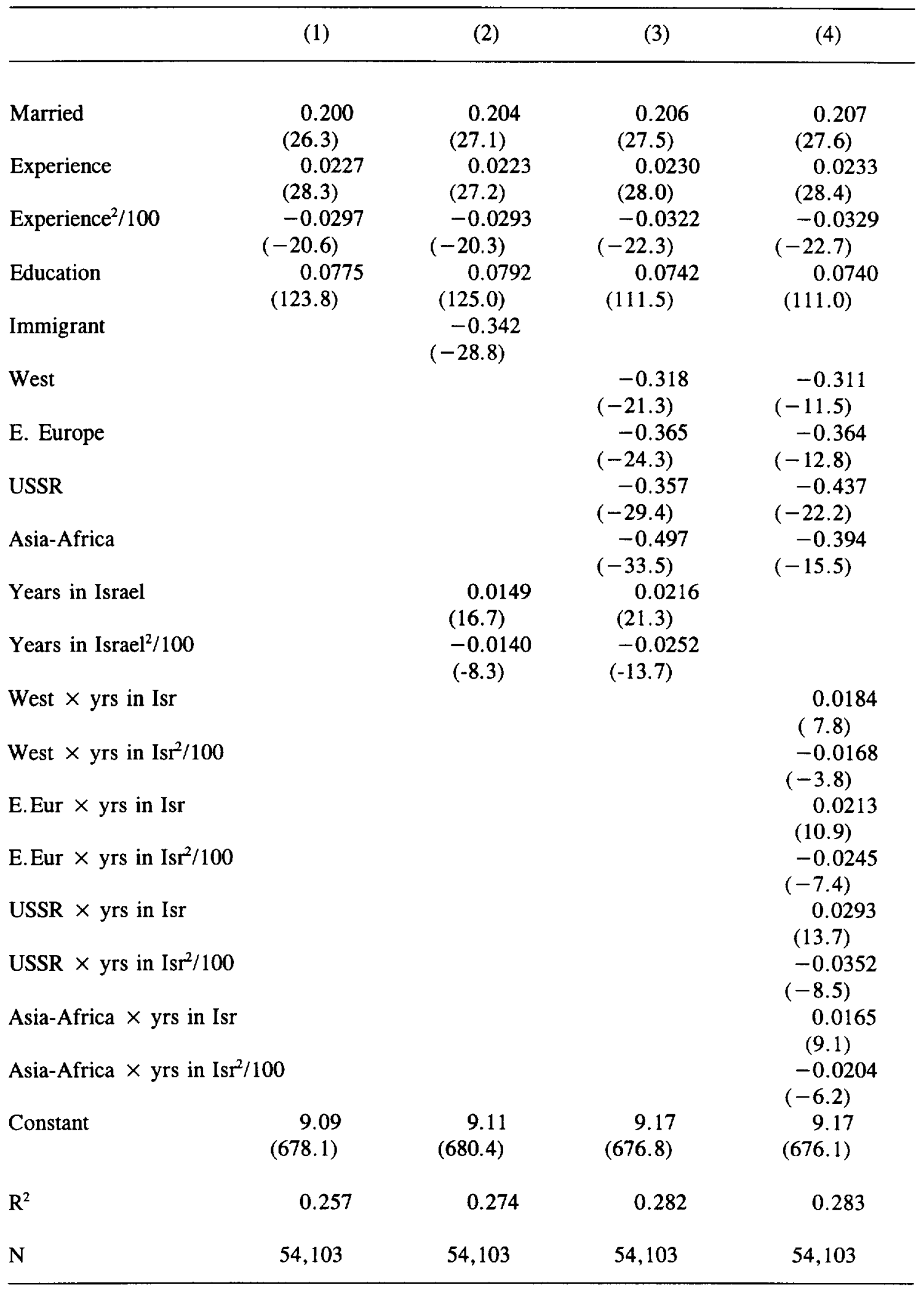

Note: Dependent variable is $\log$ monthly earnings. $t$-statistics are in parentheses. 
Table 5. Assimilation versus Cohort Quality

\begin{tabular}{|c|c|c|c|c|}
\hline & (1) & (2) & (3) & (4) \\
\hline 1983 & $\begin{array}{r}-2.58 \\
(-159.68)\end{array}$ & $\begin{array}{r}-2.60 \\
(-157.59)\end{array}$ & $\begin{array}{c}-2.63 \\
(-163.50)\end{array}$ & $\begin{array}{r}-2.63 \\
(-160.56)\end{array}$ \\
\hline Married (1972) & $\begin{array}{r}0.149 \\
(21.93)\end{array}$ & $\begin{array}{r}0.149 \\
(22.04)\end{array}$ & $\begin{array}{r}0.155 \\
(22.95)\end{array}$ & $\begin{array}{c}0.156 \\
(23.04)\end{array}$ \\
\hline Married (1983) & $\begin{array}{r}0.206 \\
(31.48)\end{array}$ & $\begin{array}{r}0.207 \\
(31.61)\end{array}$ & $\begin{array}{c}0.208 \\
(32.02)\end{array}$ & $\begin{array}{r}0.208 \\
(32.06)\end{array}$ \\
\hline Experience (1972) & $\begin{array}{l}0.0185 \\
(29.72)\end{array}$ & $\begin{array}{c}0.0181 \\
(28.83)\end{array}$ & $\begin{array}{c}0.0171 \\
(27.73)\end{array}$ & $\begin{array}{l}0.0173 \\
(27.66)\end{array}$ \\
\hline Experience (1983) & $\begin{array}{c}0.0222 \\
(31.49)\end{array}$ & $\begin{array}{l}0.0226 \\
(31.60)\end{array}$ & $\begin{array}{c}0.0233 \\
(33.22)\end{array}$ & $\begin{array}{l}0.0233 \\
(32.87)\end{array}$ \\
\hline $\operatorname{EXP}^{2} / 100(1972)$ & $\begin{array}{c}-0.0314 \\
(-29.24)\end{array}$ & $\begin{array}{c}-0.0314 \\
(-29.16)\end{array}$ & $\begin{array}{c}-0.0322 \\
(-30.23)\end{array}$ & $\begin{array}{c}-0.0327 \\
(-30.49)\end{array}$ \\
\hline $\operatorname{EXP}^{2} / 100(1983)$ & $\begin{array}{c}-0.0294 \\
(-23.66)\end{array}$ & $\begin{array}{c}-0.0301 \\
(-24.12)\end{array}$ & $\begin{array}{c}-0.0328 \\
(-26.51)\end{array}$ & $\begin{array}{c}-0.0328 \\
(-26.41)\end{array}$ \\
\hline Education (1972) & $\begin{array}{c}0.0497 \\
(102.84)\end{array}$ & $\begin{array}{c}0.0488 \\
(98.41)\end{array}$ & $\begin{array}{c}0.0425 \\
(83.21)\end{array}$ & $\begin{array}{c}0.0424 \\
(81.70)\end{array}$ \\
\hline Education (1983) & $\begin{array}{c}0.0789 \\
(145.28)\end{array}$ & $\begin{array}{c}0.0786 \\
(143.81)\end{array}$ & $\begin{array}{c}0.0738 \\
(133.34)\end{array}$ & $\begin{array}{c}0.0741 \\
(133.59)\end{array}$ \\
\hline Immigrant & $\begin{array}{r}-0.317 \\
(-48.94)\end{array}$ & $\begin{array}{r}-0.443 \\
(-16.17)\end{array}$ & & \\
\hline West & & & $\begin{array}{r}-0.232 \\
(-27.93)\end{array}$ & $\begin{array}{r}-0.373 \\
(-13.52)\end{array}$ \\
\hline E. Europe & & & $\begin{array}{r}-0.293 \\
(-40.10)\end{array}$ & $\begin{array}{r}-0.437 \\
(-15.97)\end{array}$ \\
\hline USSR & & & $\begin{array}{r}-0.293 \\
(-40.58)\end{array}$ & $\begin{array}{c}-0.422 \\
(-15.27)\end{array}$ \\
\hline Asia-Africa & & & $\begin{array}{r}-0.419 \\
(-58.40)\end{array}$ & $\begin{array}{r}-0.563 \\
(-20.55)\end{array}$ \\
\hline Years in Israel & $\begin{array}{c}0.0130 \\
(26.39)\end{array}$ & $\begin{array}{c}0.0142 \\
(15.22)\end{array}$ & $\begin{array}{c}0.0164 \\
(31.67)\end{array}$ & $\begin{array}{c}0.0155 \\
(16.73)\end{array}$ \\
\hline Years in Israel $^{2}$ & $\begin{array}{l}-0.0101 \\
(-9.94)\end{array}$ & $\begin{array}{l}-0.0130 \\
(-8.03)\end{array}$ & $\begin{array}{c}-0.0169 \\
(-16.06)\end{array}$ & $\begin{array}{l}-0.0154 \\
(-9.57)\end{array}$ \\
\hline Constant & $\begin{array}{c}11.69 \\
(1023.47)\end{array}$ & $\begin{array}{c}11.71 \\
(994.50)\end{array}$ & $\begin{array}{c}11.80 \\
(1012.84)\end{array}$ & $\begin{array}{c}11.80 \\
(988.53)\end{array}$ \\
\hline Arrival cohort dummies & No & Yes & No & Yes \\
\hline $\mathrm{R}^{2}$ & 0.849 & 0.849 & 0.851 & 0.851 \\
\hline $\mathrm{N}$ & 110,285 & 110,285 & 110,285 & 110,285 \\
\hline
\end{tabular}

Note: Pooled data from the 1972 and 1983 Censuses of Population. Dependent variable is log monthly earnings in 1983 Israeli Shekels. t-statistics are in parentheses. The arrival cohort dummies cover the years 1917-1983 in five-year intervals. The omitted dummy is the most recent one. The $\mathrm{R}^{2}$ of these regressions falls by .35 if the dependent variable is adjusted to have the same mean in the two years. 
Table 6A. The Return to Origin Country Schooling

\begin{tabular}{|c|c|}
\hline Married & $\begin{array}{l}0.196 \\
(26.1)\end{array}$ \\
\hline Experience & $\begin{array}{c}0.0269 \\
(31.3)\end{array}$ \\
\hline $\operatorname{ExP}^{2} / 100$ & $\begin{array}{l}-0.0360 \\
(-24.4)\end{array}$ \\
\hline EXP in Israel $\times$ immigrant & $\begin{array}{c}0.00586 \\
(18.0)\end{array}$ \\
\hline Immigrant & $\begin{array}{c}0.0197 \\
(1.1)\end{array}$ \\
\hline Education & $\begin{array}{l}0.0941 \\
(82.3)\end{array}$ \\
\hline Education $\times$ immigrant & $\begin{array}{c}-0.00936 \\
(-6.7)\end{array}$ \\
\hline Education abroad & $\begin{array}{l}-0.0141 \\
(-23.4)\end{array}$ \\
\hline Constant & $\begin{array}{c}8.88 \\
(466.2)\end{array}$ \\
\hline $\mathbf{R}^{2}$ & 0.278 \\
\hline $\mathbf{N}$ & 54,103 \\
\hline
\end{tabular}

Note: $\mathbf{t}$-statistics are in parentheses. Dependent variable is log monthly earnings. 
Table 6B. The Return to Origin Country Schooling

\begin{tabular}{lcccccc}
\hline & Native & Immigrant & West & E. Europe & USSR & Asia-Africa \\
& & & & & & \\
\hline Married & 0.172 & 0.201 & 0.177 & 0.250 & 0.141 & 0.189 \\
& $(16.5)$ & $(18.8)$ & $(4.9)$ & $(12.5)$ & $(4.9)$ & $(12.7)$ \\
Experience & 0.0443 & 0.00813 & 0.0261 & 0.0185 & 0.00667 & 0.00361 \\
& $(27.9)$ & $(6.5)$ & $(6.8)$ & $(6.9)$ & $(2.4)$ & $(1.8)$ \\
EXP $/ 100$ & -0.0639 & -0.0117 & -0.0526 & -0.0368 & -0.0126 & -0.00584 \\
& $(-18.7)$ & $(-6.2)$ & $(-7.5)$ & $(-9.3)$ & $(-2.6)$ & $(-2.0)$ \\
EXP in Israel & & 0.00969 & 0.0149 & 0.0101 & 0.0139 & 0.00829 \\
& & $(25.4)$ & $(10.5)$ & $(13.0)$ & $(15.9)$ & $(11.5)$ \\
ED in Israel & 0.0988 & 0.0793 & 0.0767 & 0.0713 & 0.0769 & 0.0652 \\
& $(87.0)$ & $(84.6)$ & $(23.6)$ & $(37.5)$ & $(29.2)$ & $(44.2)$ \\
ED abroad & & 0.0699 & 0.0686 & 0.0623 & 0.0629 & 0.0565 \\
& & $(94.0)$ & $(25.0)$ & $(38.6)$ & $(31.3)$ & $(48.9)$ \\
Constant & 8.66 & 9.14 & 9.04 & 9.20 & 9.30 & 9.32 \\
& $(385.4)$ & $(451.7)$ & $(136.9)$ & $(207.6)$ & $(189.9)$ & $(301.1)$ \\
& & & & & & \\
$\mathrm{R}^{2}$ & & & & & & \\
$\mathrm{~N}$ & 0.325 & 0.259 & 0.227 & 0.242 & 0.297 & 0.185 \\
& 18,488 & 35,615 & 3,209 & 10,422 & 4,587 & 17,397 \\
\hline
\end{tabular}

Note: t-statistics are in parentheses. Dependent variable is log monthly earnings. 
Table 7. Language Proficiency, Subsequent Schooling, and Experience

\begin{tabular}{|c|c|c|c|c|c|}
\hline & All & West & E. Europe & USSR & $\begin{array}{l}\text { Asia- } \\
\text { Africa }\end{array}$ \\
\hline Married & $\begin{array}{l}0.195 \\
(26.0)\end{array}$ & $\begin{array}{l}0.181 \\
(5.0)\end{array}$ & $\begin{array}{l}0.248 \\
(12.4)\end{array}$ & $\begin{array}{c}0.143 \\
(5.0)\end{array}$ & $\begin{array}{l}0.188 \\
(12.7)\end{array}$ \\
\hline Experience & $\begin{array}{l}0.0276 \\
(32.1)\end{array}$ & $\begin{array}{c}0.0239 \\
(6.2)\end{array}$ & $\begin{array}{c}0.0205 \\
(7.3)\end{array}$ & $\begin{array}{c}0.0103 \\
(3.6)\end{array}$ & $\begin{array}{c}0.00654 \\
(3.1)\end{array}$ \\
\hline $\mathrm{EXP}^{2} / 100$ & $\begin{array}{l}-0.0358 \\
(-24.3)\end{array}$ & $\begin{array}{c}-0.0488 \\
(-6.9)\end{array}$ & $\begin{array}{c}-0.0376 \\
(-9.2)\end{array}$ & $\begin{array}{c}-0.0177 \\
(-3.5)\end{array}$ & $\begin{array}{c}-0.00866 \\
(-3.0)\end{array}$ \\
\hline EXP in Israel $\times$ img & $\begin{array}{c}0.00484 \\
(8.7)\end{array}$ & $\begin{array}{c}0.0127 \\
(6.0)\end{array}$ & $\begin{array}{c}0.00847 \\
(6.4)\end{array}$ & $\begin{array}{c}0.00844 \\
(5.2)\end{array}$ & $\begin{array}{c}0.00733 \\
(7.3)\end{array}$ \\
\hline Immigrant & $\begin{array}{c}0.0529 \\
(2.5)\end{array}$ & & & & \\
\hline ED in Israel $\times$ native & $\begin{array}{l}0.0948 \\
(82.9)\end{array}$ & & & & \\
\hline ED in Israel $\times$ immigrant & $\begin{array}{c}0.0822 \\
(86.9)\end{array}$ & $\begin{array}{c}0.0800 \\
(23.5)\end{array}$ & $\begin{array}{c}0.0695 \\
(34.4)\end{array}$ & $\begin{array}{c}0.0813 \\
(27.1)\end{array}$ & $\begin{array}{c}0.0630 \\
(39.4)\end{array}$ \\
\hline ED abroad & $\begin{array}{c}0.0708 \\
(53.4)\end{array}$ & $\begin{array}{c}0.0674 \\
(17.8)\end{array}$ & $\begin{array}{l}0.0613 \\
(19.9)\end{array}$ & $\begin{array}{l}0.0601 \\
(21.0)\end{array}$ & $\begin{array}{c}0.0564 \\
(20.6)\end{array}$ \\
\hline $\begin{array}{l}\text { No Hebrew language } \\
\text { ability }\end{array}$ & $\begin{array}{c}0.0527 \\
(1.9)\end{array}$ & $\begin{array}{c}0.269 \\
(2.1)\end{array}$ & $\begin{array}{c}-0.0157 \\
(-0.3)\end{array}$ & $\begin{array}{l}0.186 \\
(3.5)\end{array}$ & $\begin{array}{c}0.0434 \\
(1.0)\end{array}$ \\
\hline No Hebrew $\times$ ED abroad & $\begin{array}{c}-0.0217 \\
(-8.2)\end{array}$ & $\begin{array}{c}-0.0251 \\
(-2.7)\end{array}$ & $\begin{array}{c}-0.0143 \\
(-2.4)\end{array}$ & $\begin{array}{c}-0.0300 \\
(-6.3)\end{array}$ & $\begin{array}{c}-0.0181 \\
(-3.7)\end{array}$ \\
\hline ED abroad $\times$ ED in Israel & $\begin{array}{c}0.00152 \\
(8.5)\end{array}$ & $\begin{array}{c}-0.00126 \\
(-2.5)\end{array}$ & $\begin{array}{c}0.00101 \\
(3.3)\end{array}$ & $\begin{array}{l}0.000468 \\
\quad(0.8)\end{array}$ & $\begin{array}{l}0.00240 \\
(8.1)\end{array}$ \\
\hline $\begin{array}{l}\text { ED abroad } \times \text { EXP in } \\
\text { Israel }\end{array}$ & $\begin{array}{c}-0.00599 \\
(-1.2)\end{array}$ & $\begin{array}{c}0.0281 \\
(1.9)\end{array}$ & $\begin{array}{c}-0.000830 \\
(-0.1)\end{array}$ & $\begin{array}{c}0.0523 \\
(3.4)\end{array}$ & $\begin{array}{c}-0.00935 \\
(-1.0)\end{array}$ \\
\hline Constant & $\begin{array}{c}8.86 \\
(465.1)\end{array}$ & $\begin{array}{c}9.07 \\
(126.6)\end{array}$ & $\begin{array}{c}9.21 \\
(197.7)\end{array}$ & $\begin{array}{c}9.28 \\
(170.8)\end{array}$ & $\begin{array}{c}9.29 \\
(270.3)\end{array}$ \\
\hline $\mathbf{R}^{2}$ & 0.282 & 0.232 & 0.246 & 0.310 & 0.189 \\
\hline $\mathrm{N}$ & 54,103 & 3,209 & 10,422 & 4,587 & 17,397 \\
\hline
\end{tabular}


Table 8. Returns to Schooling by Level and Source

\begin{tabular}{|c|c|c|c|c|c|c|}
\hline & Native & Immigrant & West & E. Europe & USSR & $\begin{array}{l}\text { Asia- } \\
\text { Africa }\end{array}$ \\
\hline Married & $\begin{array}{l}0.176 \\
(16.9)\end{array}$ & $\begin{array}{l}0.198 \\
(18.8)\end{array}$ & $\begin{array}{l}0.196 \\
(5.5)\end{array}$ & $\begin{array}{l}0.253 \\
(12.7)\end{array}$ & $\begin{array}{l}0.147 \\
(5.1)\end{array}$ & $\begin{array}{l}0.184 \\
(12.6)\end{array}$ \\
\hline Experience & $\begin{array}{l}0.0473 \\
(29.6)\end{array}$ & $\begin{array}{l}0.0152 \\
(12.1)\end{array}$ & $\begin{array}{c}0.0241 \\
(6.2)\end{array}$ & $\begin{array}{c}0.0209 \\
(7.7)\end{array}$ & $\begin{array}{c}0.0105 \\
(3.6)\end{array}$ & $\begin{array}{l}0.0137 \\
(6.6)\end{array}$ \\
\hline $\operatorname{EXP}^{2} / 100$ & $\begin{array}{l}-0.0699 \\
(-20.3)\end{array}$ & $\begin{array}{l}-0.0266 \\
(-13.6)\end{array}$ & $\begin{array}{c}-0.0484 \\
(-6.6)\end{array}$ & $\begin{array}{l}-0.0413 \\
(-10.2)\end{array}$ & $\begin{array}{c}-0.0211 \\
(-4.1)\end{array}$ & $\begin{array}{c}-0.0276 \\
(-9.3)\end{array}$ \\
\hline $\begin{array}{l}\text { EXP in Israel } \times \\
\text { img }\end{array}$ & & $\begin{array}{l}0.0108 \\
(28.2)\end{array}$ & $\begin{array}{l}0.0151 \\
(10.5)\end{array}$ & $\begin{array}{l}0.0109 \\
(13.6)\end{array}$ & $\begin{array}{l}0.0152 \\
(16.8)\end{array}$ & $\begin{array}{c}0.00974 \\
(13.7)\end{array}$ \\
\hline Primary & $\begin{array}{c}0.0317 \\
(4.7)\end{array}$ & $\begin{array}{l}0.0232 \\
(11.0)\end{array}$ & $\begin{array}{c}0.0166 \\
(1.0)\end{array}$ & $\begin{array}{c}0.0108 \\
(1.9)\end{array}$ & $\begin{array}{c}0.0117 \\
(1.4)\end{array}$ & $\begin{array}{c}0.0177 \\
(7.0)\end{array}$ \\
\hline Secondary & $\begin{array}{l}0.133 \\
(46.1)\end{array}$ & $\begin{array}{l}0.119 \\
(47.0)\end{array}$ & $\begin{array}{l}0.144 \\
(13.2)\end{array}$ & $\begin{array}{l}0.110 \\
(19.6)\end{array}$ & $\begin{array}{l}0.130 \\
(12.6)\end{array}$ & $\begin{array}{l}0.0956 \\
(29.5)\end{array}$ \\
\hline $\begin{array}{l}\text { Post - } \\
\text { secondary }\end{array}$ & $\begin{array}{l}0.0866 \\
(50.4)\end{array}$ & $\begin{array}{l}0.0819 \\
(40.8)\end{array}$ & $\begin{array}{c}0.0583 \\
(11.0)\end{array}$ & $\begin{array}{c}0.0700 \\
(20.7)\end{array}$ & $\begin{array}{c}0.0646 \\
(9.7)\end{array}$ & $\begin{array}{l}0.0867 \\
(24.7)\end{array}$ \\
\hline Primary abroad & & $\begin{array}{c}-0.000764 \\
(-0.6)\end{array}$ & $\begin{array}{c}-0.00383 \\
(-0.8)\end{array}$ & $\begin{array}{c}0.00232 \\
(0.9)\end{array}$ & $\begin{array}{c}0.00432 \\
(0.9)\end{array}$ & $\begin{array}{c}-0.00350 \\
(-2.3)\end{array}$ \\
\hline $\begin{array}{l}\text { Secondary } \\
\text { abroad }\end{array}$ & & $\begin{array}{c}-0.0281 \\
(-9.5)\end{array}$ & $\begin{array}{c}-0.0255 \\
(-2.3)\end{array}$ & $\begin{array}{c}-0.0331 \\
(-5.8)\end{array}$ & $\begin{array}{c}-0.0613 \\
(-6.0)\end{array}$ & $\begin{array}{c}-0.0143 \\
(-3.4)\end{array}$ \\
\hline $\begin{array}{l}\text { Post-secondary } \\
\text { abroad }\end{array}$ & & $\begin{array}{c}-0.00648 \\
(-2.3)\end{array}$ & $\begin{array}{c}0.00340 \\
(0.5)\end{array}$ & $\begin{array}{c}-0.00420 \\
(-0.8)\end{array}$ & $\begin{array}{c}0.0121 \\
(1.5)\end{array}$ & $\begin{array}{c}-0.0168 \\
(-2.7)\end{array}$ \\
\hline Constant & $\begin{array}{c}9.07 \\
(168.6)\end{array}$ & $\begin{array}{c}9.36 \\
(432.9)\end{array}$ & $\begin{array}{c}9.32 \\
(70.5)\end{array}$ & $\begin{array}{c}9.49 \\
(175.8)\end{array}$ & $\begin{array}{c}9.57 \\
(155.3)\end{array}$ & $\begin{array}{c}9.47 \\
(302.4)\end{array}$ \\
\hline $\mathrm{R}^{2}$ & 0.332 & 0.277 & 0.239 & 0.252 & 0.310 & 0.210 \\
\hline $\mathrm{N}$ & 18,488 & 35,615 & 3,209 & 10,422 & 4,587 & 17,397 \\
\hline
\end{tabular}

Note: t-statistics are in parentheses. Dependent variable is log monthly earnings. Primary, Secondary, and Post-Secondary indicate years of schooling completed at that level. 
Table 9A. Returns to Different Configurations of Schooling

\begin{tabular}{|c|c|}
\hline Married & $\begin{array}{l}0.201 \\
(26.5)\end{array}$ \\
\hline Experience & $\begin{array}{l}0.0311 \\
(35.0)\end{array}$ \\
\hline $\operatorname{EXP}^{2} / 100$ & $\begin{array}{c}-0.0479 \\
(-30.7)\end{array}$ \\
\hline EXP in Israel $\times$ img & $\begin{array}{c}0.00705 \\
(21.0)\end{array}$ \\
\hline Immigrant & $\begin{array}{l}-0.153 \\
(-17.4)\end{array}$ \\
\hline III & $\begin{array}{l}1.024 \\
(59.4)\end{array}$ \\
\hline IIO & $\begin{array}{l}0.523 \\
(31.1)\end{array}$ \\
\hline IOO & $\begin{array}{l}0.172 \\
(9.9)\end{array}$ \\
\hline FFF & $\begin{array}{l}0.837 \\
(49.6)\end{array}$ \\
\hline FFO & $\begin{array}{l}0.400 \\
(25.4)\end{array}$ \\
\hline FOO & $\begin{array}{c}0.125 \\
(8.3)\end{array}$ \\
\hline FFI & $\begin{array}{l}0.930 \\
(41.0)\end{array}$ \\
\hline FII & $\begin{array}{l}0.969 \\
(47.1)\end{array}$ \\
\hline FIO & $\begin{array}{l}0.501 \\
(27.5)\end{array}$ \\
\hline Constant & $\begin{array}{c}9.36 \\
(482.5)\end{array}$ \\
\hline $\mathbf{R}^{2}$ & 0.268 \\
\hline $\mathrm{N}$ & 54,103 \\
\hline
\end{tabular}

Note: t-statistics are in parentheses. Dependent variable is log monthly earnings. The three-letter combinations (FIO, etc.) are dummy variables that are interpreted as follows: The first letter indicates the location of primary school, the second the location if secondary school, and the third the location of postsecondary school. F indicates foreign, I indicates Israel, and $\mathrm{O}$ indicates none. $\mathrm{OOO}$ is the omitted category. 
Table 9B. Returns to Different Configurations of Schooling

\begin{tabular}{|c|c|c|c|c|c|c|}
\hline & Native & Immigrant & West & E. Europe & USSR & Asia-Africa \\
\hline Married & $\begin{array}{l}0.183 \\
(17.2)\end{array}$ & $\begin{array}{l}0.202 \\
(18.9)\end{array}$ & $\begin{array}{l}0.233 \\
(6.4)\end{array}$ & $\begin{array}{l}0.247 \\
(12.3)\end{array}$ & $\begin{array}{l}0.142 \\
(4.9)\end{array}$ & $\begin{array}{l}0.187 \\
(12.6)\end{array}$ \\
\hline Experience & $\begin{array}{l}0.0454 \\
(27.8)\end{array}$ & $\begin{array}{c}0.0123 \\
(9.7)\end{array}$ & $\begin{array}{c}0.0182 \\
(4.6)\end{array}$ & $\begin{array}{c}0.0215 \\
(7.9)\end{array}$ & $\begin{array}{c}0.0111 \\
(3.7)\end{array}$ & $\begin{array}{c}0.0111 \\
(5.4)\end{array}$ \\
\hline $\mathrm{EXP}^{2} / 100$ & $\begin{array}{l}-0.0681 \\
(-19.4)\end{array}$ & $\begin{array}{c}-0.0244 \\
(-12.4)\end{array}$ & $\begin{array}{c}-0.0437 \\
(-5.9)\end{array}$ & $\begin{array}{c}-0.0442 \\
(-10.7)\end{array}$ & $\begin{array}{c}-0.0237 \\
(-4.6)\end{array}$ & $\begin{array}{c}-0.0254 \\
(-8.5)\end{array}$ \\
\hline $\begin{array}{l}\text { EXP in Israel } \times \\
\text { img }\end{array}$ & & $\begin{array}{l}0.0114 \\
(28.5)\end{array}$ & $\begin{array}{c}0.0164 \\
(10.7)\end{array}$ & $\begin{array}{c}0.0108 \\
(13.1)\end{array}$ & $\begin{array}{l}0.0158 \\
(16.7)\end{array}$ & $\begin{array}{c}0.00986 \\
(13.5)\end{array}$ \\
\hline III & $\begin{array}{l}1.098 \\
(16.0)\end{array}$ & $\begin{array}{l}0.967 \\
(49.8)\end{array}$ & $\begin{array}{l}0.978 \\
(6.0)\end{array}$ & $\begin{array}{l}0.835 \\
(13.5)\end{array}$ & $\begin{array}{l}0.826 \\
(11.5)\end{array}$ & $\begin{array}{l}0.765 \\
(29.7)\end{array}$ \\
\hline IIO & $\begin{array}{c}0.584 \\
(8.6)\end{array}$ & $\begin{array}{l}0.473 \\
(26.1)\end{array}$ & $\begin{array}{l}0.533 \\
(3.2)\end{array}$ & $\begin{array}{l}0.386 \\
(6.3)\end{array}$ & $\begin{array}{l}0.432 \\
(6.0)\end{array}$ & $\begin{array}{l}0.355 \\
(16.5)\end{array}$ \\
\hline IOO & $\begin{array}{l}0.215 \\
(3.1)\end{array}$ & $\begin{array}{l}0.128 \\
(6.6)\end{array}$ & $\begin{array}{c}0.0849 \\
(0.5)\end{array}$ & $\begin{array}{c}0.0403 \\
(0.6)\end{array}$ & $\begin{array}{l}-0.0925 \\
(-1.0)\end{array}$ & $\begin{array}{c}0.0796 \\
(3.6)\end{array}$ \\
\hline FFF & & $\begin{array}{l}0.839 \\
(48.2)\end{array}$ & $\begin{array}{l}0.927 \\
(5.7)\end{array}$ & $\begin{array}{l}0.675 \\
(11.3)\end{array}$ & $\begin{array}{l}0.626 \\
(10.0)\end{array}$ & $\begin{array}{l}0.671 \\
(27.1)\end{array}$ \\
\hline FFO & & $\begin{array}{l}0.408 \\
(25.1)\end{array}$ & $\begin{array}{l}0.461 \\
(2.9)\end{array}$ & $\begin{array}{c}0.326 \\
(5.6)\end{array}$ & $\begin{array}{l}0.252 \\
(4.1)\end{array}$ & $\begin{array}{l}0.302 \\
(15.8)\end{array}$ \\
\hline FOO & & $\begin{array}{c}0.136 \\
(8.7)\end{array}$ & $\begin{array}{l}0.185 \\
(1.1)\end{array}$ & $\begin{array}{c}0.0971 \\
(1.7)\end{array}$ & $\begin{array}{c}0.0636 \\
(1.0)\end{array}$ & $\begin{array}{c}0.0602 \\
(3.5)\end{array}$ \\
\hline FFI & & $\begin{array}{l}0.876 \\
(37.6)\end{array}$ & $\begin{array}{c}0.858 \\
(5.1)\end{array}$ & $\begin{array}{l}0.703 \\
(10.8)\end{array}$ & $\begin{array}{c}0.640 \\
(8.3)\end{array}$ & $\begin{array}{l}0.789 \\
(23.1)\end{array}$ \\
\hline FII & & $\begin{array}{l}0.917 \\
(43.1)\end{array}$ & $\begin{array}{c}0.843 \\
(5.1)\end{array}$ & $\begin{array}{l}0.766 \\
(12.2)\end{array}$ & $\begin{array}{l}0.784 \\
(10.5)\end{array}$ & $\begin{array}{l}0.771 \\
(26.0)\end{array}$ \\
\hline FIO & & $\begin{array}{l}0.469 \\
(24.8)\end{array}$ & $\begin{array}{l}0.566 \\
(3.4)\end{array}$ & $\begin{array}{c}0.390 \\
(6.3)\end{array}$ & $\begin{array}{c}0.349 \\
(4.7)\end{array}$ & $\begin{array}{l}0.340 \\
(15.1)\end{array}$ \\
\hline Constant & $\begin{array}{c}9.15 \\
(135.2)\end{array}$ & $\begin{array}{c}9.43 \\
(415.8)\end{array}$ & $\begin{array}{c}9.37 \\
(57.3)\end{array}$ & $\begin{array}{c}9.52 \\
(139.6)\end{array}$ & $\begin{array}{c}9.63 \\
(133.0)\end{array}$ & $\begin{array}{c}9.55 \\
(304.3)\end{array}$ \\
\hline $\mathrm{R}^{2}$ & 0.297 & 0.258 & 0.215 & 0.238 & 0.281 & 0.200 \\
\hline $\mathbf{N}$ & 18,488 & 35,615 & 3,209 & 10,422 & 4,587 & 17,397 \\
\hline
\end{tabular}

Note: t-statistics are in parentheses. Dependent variable is log monthly earnings. The three-letter combinations (FIO, etc.) are dummy variables that are interpreted as follows: The first letter indicates the location of primary school, the second the location of secondary school, and the third the location of postsecondary school. F indicates foreign, $I$ indicates Israel, and $O$ indicates none. OOO is the omitted category. 
Table 10. Differences in the Returns to Different Configurations of Schooling

\begin{tabular}{|c|c|c|c|c|c|c|}
\hline & Native & Immigrant & West & E. Europe & USSR & Asia-Africa \\
\hline III-IIO & $\begin{array}{c}0.5140 \\
(0.0080)\end{array}$ & $\begin{array}{c}0.4944 \\
(0.0120)\end{array}$ & $\begin{array}{c}0.4453 \\
(0.0367)\end{array}$ & $\begin{array}{c}0.4486 \\
(0.0229)\end{array}$ & $\begin{array}{c}0.3946 \\
(0.0470)\end{array}$ & $\begin{array}{c}0.4102 \\
(0.0176)\end{array}$ \\
\hline IIO-IOO & $\begin{array}{c}0.3696 \\
(0.0117)\end{array}$ & $\begin{array}{c}0.3446 \\
(0.0126)\end{array}$ & $\begin{array}{c}0.4482 \\
(0.0701)\end{array}$ & $\begin{array}{c}0.3459 \\
(0.0378)\end{array}$ & $\begin{array}{c}0.5243 \\
(0.0728)\end{array}$ & $\begin{array}{c}0.2753 \\
(0.0139)\end{array}$ \\
\hline FFF-FFO & & $\begin{array}{c}0.4305 \\
(0.0098)\end{array}$ & $\begin{array}{c}0.4661 \\
(0.0318)\end{array}$ & $\begin{array}{c}0.3487 \\
(0.0181)\end{array}$ & $\begin{array}{c}0.3746 \\
(0.0184)\end{array}$ & $\begin{array}{c}0.3692 \\
(0.0199)\end{array}$ \\
\hline FFO-FOO & & $\begin{array}{c}0.2725 \\
(0.0079)\end{array}$ & $\begin{array}{c}0.7423 \\
(0.04802)\end{array}$ & $\begin{array}{c}0.2293 \\
(0.0157)\end{array}$ & $\begin{array}{c}0.1880 \\
(0.0231)\end{array}$ & $\begin{array}{c}0.2414 \\
(0.0119)\end{array}$ \\
\hline III-FFF & & $\begin{array}{c}0.1286 \\
(0.0129)\end{array}$ & $\begin{array}{c}0.0514 \\
(0.0324)\end{array}$ & $\begin{array}{c}0.1597 \\
(0.0241)\end{array}$ & $\begin{array}{c}0.2002 \\
(0.0373)\end{array}$ & $\begin{array}{c}0.0943 \\
(0.0247)\end{array}$ \\
\hline III-FFI & & $\begin{array}{c}0.0916 \\
(0.0193)\end{array}$ & $\begin{array}{c}0.1207 \\
(0.0482)\end{array}$ & $\begin{array}{c}0.1318 \\
(0.0332)\end{array}$ & $\begin{array}{c}0.1864 \\
(0.0560)\end{array}$ & $\begin{array}{l}-0.0240 \\
(0.0325)\end{array}$ \\
\hline III-FII & & $\begin{array}{c}0.0501 \\
(0.0166)\end{array}$ & $\begin{array}{c}0.1351 \\
(0.0498)\end{array}$ & $\begin{array}{c}0.0685 \\
(0.0264)\end{array}$ & $\begin{array}{c}0.0424 \\
(0.0518)\end{array}$ & $\begin{array}{l}-0.0061 \\
(0.0271)\end{array}$ \\
\hline FFI-FFF & & $\begin{array}{c}0.0370 \\
(0.0183)\end{array}$ & $\begin{array}{l}-0.0692 \\
(0.0462)\end{array}$ & $\begin{array}{c}0.0279 \\
(0.0320)\end{array}$ & $\begin{array}{c}0.0138 \\
(0.0475)\end{array}$ & $\begin{array}{c}0.1183 \\
(0.0337)\end{array}$ \\
\hline FII-FFF & & $\begin{array}{c}0.0785 \\
(0.0157)\end{array}$ & $\begin{array}{c}-0.0836 \\
(0.0480)\end{array}$ & $\begin{array}{c}0.0912 \\
(0.2259)\end{array}$ & $\begin{array}{c}0.1579 \\
(0.0427)\end{array}$ & $\begin{array}{c}0.1004 \\
(0.0288)\end{array}$ \\
\hline IIO-FFO & & $\begin{array}{c}0.0647 \\
(0.0119)\end{array}$ & $\begin{array}{c}0.0723 \\
(0.0397)\end{array}$ & $\begin{array}{c}0.0598 \\
(0.0218)\end{array}$ & $\begin{array}{c}0.1802 \\
(0.0374)\end{array}$ & $\begin{array}{c}0.0533 \\
(0.0142)\end{array}$ \\
\hline IOO-FOO & & $\begin{array}{l}-0.0074 \\
(0.0130)\end{array}$ & $\begin{array}{c}-0.0998 \\
(0.0790)\end{array}$ & $\begin{array}{l}-0.0568 \\
(0.0014)\end{array}$ & $\begin{array}{l}-0.1561 \\
(0.0702)\end{array}$ & $\begin{array}{c}0.0194 \\
(0.0147)\end{array}$ \\
\hline FIO-FFO & & $\begin{array}{c}0.061 \\
(.0118)\end{array}$ & $\begin{array}{c}0.105 \\
(.0486)\end{array}$ & $\begin{array}{c}0.064 \\
(.0221)\end{array}$ & $\begin{array}{c}0.097 \\
(.0417)\end{array}$ & $\begin{array}{c}0.038 \\
(.0159)\end{array}$ \\
\hline FIO-FOO & & $\begin{array}{c}0.333 \\
(.0123)\end{array}$ & $\begin{array}{c}0.381 \\
(.0607)\end{array}$ & $\begin{array}{l}0.2929 \\
(.0242)\end{array}$ & $\begin{array}{l}0.3264 \\
(.0450)\end{array}$ & $\begin{array}{l}0.2798 \\
(.0156)\end{array}$ \\
\hline IIO-FIO & & $\begin{array}{c}0.0041 \\
(0.0120)\end{array}$ & $\begin{array}{c}-0.0324 \\
(0.0487)\end{array}$ & $\begin{array}{l}-0.0042 \\
(0.0243)\end{array}$ & $\begin{array}{c}0.0831 \\
(0.0503)\end{array}$ & $\begin{array}{c}0.0146 \\
(0.0147)\end{array}$ \\
\hline FFI-FFO & & $\begin{array}{c}0.4676 \\
(0.0182)\end{array}$ & $\begin{array}{c}0.3969 \\
(0.0509)\end{array}$ & $\begin{array}{c}0.3766 \\
(0.0312)\end{array}$ & $\begin{array}{c}0.3884 \\
(0.0480)\end{array}$ & $\begin{array}{c}0.4874 \\
(0.0303)\end{array}$ \\
\hline
\end{tabular}

Note: Measures are the difference in log earnings for people with the specified configurations of schooling, derived from Table 9B. See the note following Table 9B for an explanation of these schooling variables. Standard errors on the differences are in parentheses. 
Figure One

Earnings and Years Since Immigration

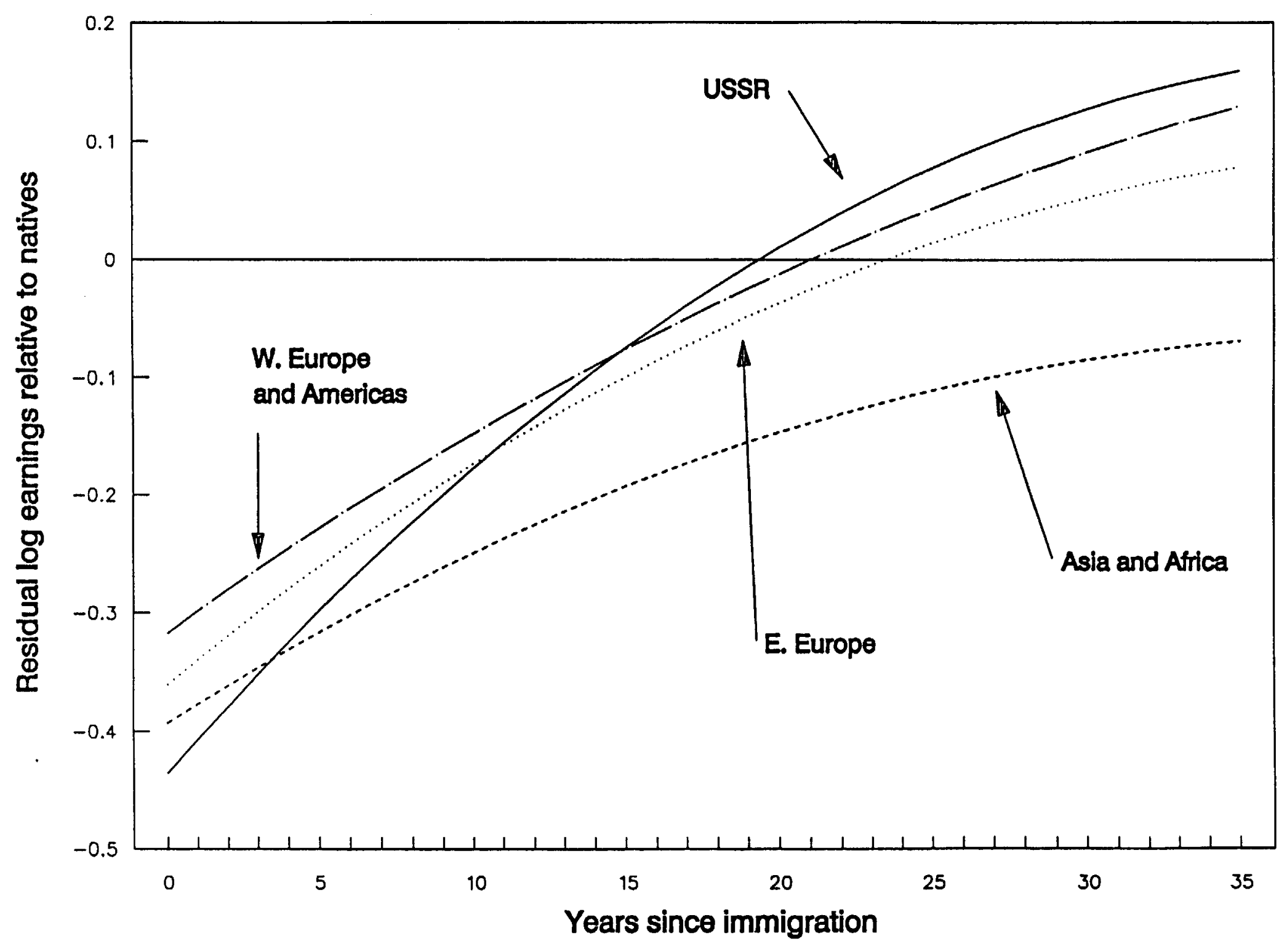




\section{References}

Amir, Shmuel. "Trends in Wage Differentials Between Jewish Males of Different Ethnic Origin During the 1970s." Bank of Israel Economic Review (December 1988):

Bahral, Uri. The Effect of Mass Immigration on Wages in Israel. Jerusalem: Falk Project for Economic Research in Israel, 1965.

Baker, Michael; and Dwayne Benjamin. "The Performance of Immigrants in the Canadian Labor Market." Journal of Labor Economics 12 (1994):

Becker, Gary. Human Capital. Chicago: University of Chicago Press, 1975.

Beenstock, Michael. "Learning Hebrew and Finding a Job: An Econometric Analysis of Immigrant Absorption in Israel." Discussion Paper no.93.05. Jerusalem: Maurice Falk Institute for Economic Research in Israel, 1993.

Beggs, John; and Bruce Chapman. "Male Immigrant Wage and Unemployment Experience in Australia." In Immigration, Trade and the Labor Market, edited by J. Abowd and R. Freeman. Chicago: University of Chicago Press, 1991.

Ben-Porath, Yoram. "Diversity in Population and in the Labor Force." In The Israeli Economy: Maturing Through Crises, edited by Y. Ben-Porath. Cambridge, MA: Harvard University Press, 1986.

Bloom, David; and Gilles Grenier. "Earnings of the French Minority in Canada and the Spanish Minority in the United States." In Immigration, Language, and Ethnicity: Canada and the United States, edited by Barry Chiswick. Washington, D.C.: American Enterprise Institute (1992): 373-409.

Bloom, David; and Morley Gunderson. "An Analysis of the Earnings of Canadian Immigrants." In Immigration, Trade and the Labor Market, edited by J. Abowd and R. Freeman. Chicago: University of Chicago Press, 1991.

Borjas, George. "The Earnings of Male Hispanic Immigrants in the United States." Industrial and Labor Relations Review 35.2 (1982):

" Assimilation, Changes in Cohort Quality, and the Earnings of Immigrants." Journal of Labor Economics (1985):

"Self-Selection and the Earnings of Immigrants." American Economic Review 77 (1987):

Friends or Strangers: The Impact of Immigrants on the U.S. Economy. New York: Basic Books, 1990.

_. "National Origin and the Skills of Immigrants in the Postwar Period." In Immigration and 
the Workforce, edited by G. Borjas and R. Freeman. Chicago: University of Chicago Press, 1992.

Butcher, Kristin. "Black Immigrants in the United States: A Comparison with Native Blacks and Other Immigrants." Industrial and Labor Relations Review 47 (January 1994):

Carliner, Geoffrey. "Wages, Earnings and Hours of First, Second, and Third Generation American Males." Economic Inquiry (January 1980):

Chapman, Bruce, and Robyn Iredale. "Immigrant Qualifications: Recognition and Relative Wage Outcomes." Discussion Paper no.240. London: CEPR, August 1990.

Chiswick, Barry. "The Effect of Americanization on the Earnings of Foreign-Born Men." Journal of Political Economy 86 (October 1978a): 897-922.

_. "A Longitudinal Analysis of the Occupational Mobility of Immigrants." Proceedings of the 30th Annual Winter Meeting, Industrial Relations Research Association (1978b):

"The Economic Progress of Immigrants: Some Apparently Universal Patterns." In Contemporary Economic Problems, edited by W. Fellner. Washington, D.C.: American Enterprise Institute (1979): 119-158.

. "Is the New Immigration Less Skilled Than the Old?." Journal of Labor Economics 4 (1986):

_. "Speaking, Reading, and Earnings Among Low-Skilled Immigrants." Journal of Labor Economics 9 (1991):

Chiswick, Barry and Paul Miller. "Language in the Immigrant Labor Market." In Immigration, Language and Ethnicity, edited by Barry Chiswick. Washington, D.C.: AEI Press (1992): 229-296.

Flug, Karnit, Nitsa (Kaliner) Kasir, and Gur Ofer. "The Absorption of Soviet Immigrants into the Labor Market from 1990 Onwards: Aspects of Occupational Substitution and Retention." Discussion Paper 92.13. Jerusalem: Bank of Israel, 1992.

Friedberg, Rachel. "The Labor Market Assimilation of Immigrants in the United States: The Role of Age at Arrival." MIT mimeo (1992).

. "The Success of Young Immigrants in the U.S. Labor Market: An Evaluation of Competing Explanations." Brown University mimeo (1993).

Funkhouser, Edward, and Stephen Trejo. "The Decline in Immigrant Labor Market Skills:

Did it Continue in the 1980s?" University of California Santa Barbara mimeo (1992).

Israel Central Bureau of Statistics. Census of Population and Housing 1972. Jerusalem: CBS, 1974. 
_. Census of Population and Housing 1983. Jerusalem: CBS. 1985.

Jasso, Guillermina and Mark Rosenzweig. "How Well Do U.S. Immigrants Do? Vintage Effects, Emigration Selectivity, and Occupational Mobility." Research in Human Capital and Development, 1988.

—. The New Chosen People. New York: Russell Sage, 1990.

Kossoudji, Sherrie. "English Language Ability and the Labor Market Opportunities of Hispanic and East Asian Immigrant Men." Journal of Labor Economics 6 (1988):

—. "Immigrant Worker Assimilation: Is It a Labor Market Phenomenon?" Journal of Human Resources 24 (1989):

LaLonde, Robert; and Robert Topel. "The Assimilation of Immigrants in the U.S. Labor Market." In Immigration and the Workforce, edited by G. Borjas and R. Freeman. Chicago: University of Chicago Press, 1992.

McManus, Walter, William Gould, and Finis Welch. "Earnings of Hispanic Men: The Role of English Language Proficiency." Journal of Labor Economics 1 (April 1983): 101-130.

Mincer, Jacob. Schooling, Experience, and Earnings. New York: Columbia University Press, 1974.

Ofer, Gur; Aaron Vinokur; and Yarom Ariav. Klita B'Avoda Shel Olei Brit Hamoatsot B'Yisrael (Work Absorption of Soviet Immigrants in Israel: A Comparative Analysis.), Report to the Ministry of Labor, 1983.

Razin, Assaf, and Efraim Sadka. The Economy of Modern Israel. Chicago: University of Chicago Press, 1993.

Rivlin, Paul. The Israeli Economy. Boulder: Westview Press, 1992.

Sabatello, Eitan. "Patterns of Occupational Mobility Among New Immigrants to Israel." International Migration (1979):

Sjaastad, Larry. "The Costs and Returns of Human Migration." Journal of Political Economy (1962):

Stark, Oded. The Migration of Labor. Cambridge, MA: Basil Blackwell, 1991.

Willis, Robert. "Wage Determinants: A Survey and Reinterpretation of Human Capital Earnings Functions." Handbook of Labor Economics, edited by O. Ashenfelter and R. Layard. Amsterdam: North Holland, 1986. 